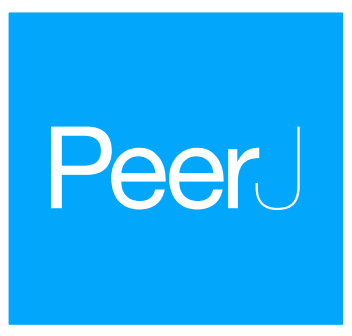

\title{
A quantitative approach to determine the taxonomic identity and ontogeny of the pycnodontiform fish Pycnodus (Neopterygii, Actinopterygii) from the Eocene of Bolca Lagerstätte, Italy
}

\author{
John Joseph Cawley ${ }^{1}$, Giuseppe Marramà ${ }^{1}$, Giorgio Carnevale ${ }^{2}$ and \\ Jürgen Kriwet ${ }^{1}$ \\ ${ }^{1}$ University of Vienna, Department of Palaeontology, Vienna, Austria \\ ${ }^{2}$ Dipartimento di Scienze della Terra, Università degli Studi di Torino, Turin, Italy
}

\section{ABSTRACT}

Background: The pycnodontiform fish Pycnodus is one of the representatives of the highly diverse actinopterygian fish fauna from the early Eocene Bolca Lagerstätte, representing one of the youngest and thus last occurrences of this extinct neopterygian clade. This genus has historically been used as a wastebasket taxon in regards to poorly known pycnodontiform fossils. Authors have argued over the specific status of the Bolca Lagerstätte Pycnodus in terms of how many species are contained within the genus with some arguing for multiple species and others suggesting lumping all Bolca specimens together into one species.

Methods: Here, we use a quantitative approach performing biometric and geometric morphometric analyses on 52 specimens of Pycnodus in order to determine if the morphological variability within the sample might be related to inter- or intraspecific variation.

Results: The analyses revealed that the variations of body shape, morphometric and meristic characters cannot be used to distinguish different morphotypes. On the

Submitted 26 February 2018

Accepted 28 April 2018

Published 18 May 2018

Corresponding author

John Joseph Cawley,

john.cawley@univie.ac.at

Academic editor

Kenneth De Baets

Additional Information and

Declarations can be found on page 21

DOI 10.7717/peerj.4809

(c) Copyright

2018 Cawley et al.

Distributed under

Creative Commons CC-BY 4.0

\section{OPEN ACCESS}

contrary, our results show a remarkable link between shape and size, related to ontogeny.

Discussion: Differences in body shape of small (juvenile) and large (adult) individuals is probably related to different microhabitats occupation on the Bolca reef with juveniles sheltering within crevices on the reef and adults being more powerful swimmers that swim above the coral. Taxonomically, we suggest that the Bolca Pycnodus should be referred to strictly as Pycnodus apodus as this was the name given to the holotype. Additionally, an overview of species assigned to Pycnodus is given.

Subjects Ecology, Evolutionary Studies, Paleontology, Taxonomy

Keywords Growth, Habitat use, Geometric morphometrics, Pycnodontiformes, Palaeogene

\section{INTRODUCTION}

Pycnodontiform fishes were a highly successful group of neopterygian fishes that colonized shallow marine, brackish, and freshwater habitats from the Norian to the 
middle Eocene during ca. $170 \mathrm{Ma}$ (Tintori, 1981; Longbottom, 1984; Poyato-Ariza et al., 1998; Kriwet, 2005). They were particularly diverse during the Late Cretaceous when they showed the highest degree of morphological diversity (Marramà et al., 2016a; Cawley \& Kriwet, 2018). Pycnodonts underwent a severe drop in their diversity and disparity at the end of the Cretaceous, and the last representatives survived in restricted biotopes until the Middle Eocene (Poyato-Ariza, 2005; Marramà et al., 2016a). One of the last Palaeogene representatives is Pycnodus apodus (Volta, 1796), which is represented by several complete and articulated skeletons from the early Eocene (late Ypresian, c. 49 Ma) (Papazzoni et al., 2014; Marramà et al., 2016b) Bolca Koservat-Lagerstätte. This deposit yielded a huge amount of exquisitely preserved fishes, which are housed today in several museums and research institutions around the world, and that are represented by more than 230 bony and cartilaginous fish species (see e.g., Blot, 1987; Blot \& Tyler, 1990; Bannikov, 2004, 2006, 2008; Bannikov \& Carnevale, 2009, 2010, 2016; Carnevale \& Pietsch, 2009, 2010, 2011, 2012; Carnevale et al., 2014, 2017; Marramà \& Carnevale, 2015a, 2015b, 2016, 2017; Marramà et al., 2017a, 2017b).

Pycnodus apodus has a long and complex taxonomic history (see e.g., Blot, 1987; Poyato-Ariza \& Wenz, 2002). Volta (1796) originally designated it as Coryphaena apoda. Blainville (1818) subsequently redescribed the same specimens without illustrations, and erected for them the taxon Zeus platessus. Finally, Agassiz (1833-1844) created the genus Pycnodus for these specimens but kept the specific name of Blainville (1818). Agassiz (1833-1844) noted that the existence of small specimens with a swelling of the forehead to be juveniles of $P$. platessus. Heckel (1856) erected using the same material as Agassiz (but probably also including other specimens) from Bolca a second species of Pycnodus, P. gibbus, due to differential characters such as the presence of a gibbosity on the forehead, higher vertebrae length to body depth ratio than $P$. platessus and the body depth being one and a half times that of the body length in contrast to P. platessus having a body depth half that of the length. Another character not explicitly mentioned in the text but was drawn (Heckel, 1856, Plate 8, Fig. 4) is that P. gibbus has two interdigitations between the vertebrae while $P$. platessus has three to four. More recently, Blot (1987) examined specimens that were labeled $P$. platessus in various institutional collections and compared their anatomy to that of specimens labeled P. gibbus and concluded that $P$. gibbus is synonymous with $P$. platessus and variations recorded among specimens were due to intraspecific differences. However, this hypothesis has never been tested employing a robust quantitative approach. Traditional and geometric morphometrics (Zelditch et al., 2004) have been successfully used to interpret the patterns of morphospace occupation, quantifying the morphological diversification, solving taxonomic debates, as well as to test if morphometric variations are due to intra- or interspecific variability (Wretman, Blom \& Kear, 2016; Marramà \& Carnevale, 2017; Marramà et al., 2017c).

In this perspective, this paper aims to analyze if the morphometric variation among Pycnodus species of Bolca, can be related to interspecific or intraspecific variability as hypothesized by Blot (1987). For this, we examined abundant Pycnodus specimens 
from various museum collections which were labeled as either P. apodus, P. platessus, P. gibbus or Pycnodus sp. to establish whether these species separate substantially from each other in the morphospace and if morphometric and meristic data can be useful to detect significant differences between the labeled taxa. Since the studied sample had a range of specimens of different sizes, we investigated whether different shapes can be related to possible ontogenetic differences of Pycnodus representing different growth stages from juvenile to adult.

\section{The taxonomic history of Pycnodus}

Pycnodus has long been used as wastebasket taxon in the study of pycnodontiforms, being used as a default name particularly for many Mesozoic taxa. Later revisions revealed said taxa to have significant morphological differences with Pycnodus leading to the creation of new genera. Species of pycnodontiforms previously referred to as Pycnodus include Anomoeodus subclavatus from the Maastrichtian of the Netherlands (Agassiz, 1833; Davis, 1890; Forir, 1887); other species of Anomoeodus referred to as Pycnodus include A. angustus, A. muensteri, A. phaseolus, A. sculptus (Agassiz 1833-1844) and A. distans (Coquand, 1860; Sauvage, 1880). P. liassicus Egerton, 1855 from the Early Jurassic, of Barrow-on-Soar of Leicestershire, UK was assigned to the genus Eomesodon by Woodward (1918) and Stemmatodus rhombus (Agassiz, 1833-1844) from the Early Cretaceous of Capo d'Orlando, close to Naples, Italy was originally named P. rhombus (see Heckel, 1854). P. flabellatum Cope, 1886 from the Cenomanian-Coniacian of Brazil was assigned to Nursallia flabellatum by Blot (1987). The pycnodonts P. achillis Costa, 1853, P. grandis Costa, 1853, and P. rotundatus Costa, 1864 are all synonymous with Ocloedus costae (d'Erasmo, 1914, Poyato-Ariza \& Wenz, 2002). Poyato-Ariza (2013) revised "Pycnodus" laveirensis Veiga Ferreira, 1961 from the Cenomanian of Lavieras, Portugal and found that due to morphological differences in characters such as absence of dermocranial fenestra, number of premaxillary teeth, contact type of arcocentra and median fin morphology, it represents a member of a different genus and consequently erected the new genus Sylvienodus as a replacement. An articulated specimen of "Pycnodus" was found in the Campanian-Maastrichtian of Nardò, Italy, which certainly represents a different pycnodont (Taverne, 1997). An extremely fragmentary specimen referred to as "Pycnodus" nardoensis from Apulia (Nardò), Italy is comprised of the anterior part of the body along with some posterior elements of the skull (Taverne, 1997). However, in a later study Taverne (2003) studied new material of this taxon, which revealed that this species does not belong to Pycnodus due to the possession of a narrower cleithrum and peculiar morphology of the contour scales. This new data led to the creation of the new genus Pseudopycnodus to allocate the Nardò material.

All other Mesozoic species of Pycnodus are based on isolated dentitions or teeth. The earliest records of Pycnodus are dentitions found in the limestones from the Upper Jurassic (Kimmeridgian) of Orbagnoux, France (Sauvage, 1893). Isolated teeth and an isolated vomerine dentition were referred to cf. Pycnodus sp. (Goodwin et al., 1999) from the Mugher Mudstone formation of the Tithonian. However, its identity is doubted due to the 
stratigraphic position and could be attributed to Macromesodon (Kriwet, 2001b). Pictet, Campiche \& de Tribolet (1858-60) described remains of the Early Cretaceous fish assemblages from Switzerland where three species of Macromesodon (M. couloni from the Hauterivian and Barremian, M. cylindricus from the Valanginian, Barremian, and Aptian and M. obliqus from the Albian) were all originally referred to as Pycnodus. Isolated dentitions belonging to "Pycnodus" heterotypus and "Pycnodus" quadratifer were reported from the Hauterivian of the Paris basin (Cornuel, 1883, 1886). Several isolated teeth derived from the Cenomanian strata of the Chalk Group of southern England were attributed to P. scrobiculatus Reuss, 1845 whose systematic affinity is still uncertain. Other teeth belonging to P. scrobiculatus were reported from the Turonian of northern Germany. Roemer (1841) described isolated remains belonging to P. harlebeni from the Late Cretaceous of Hilsconglomerat of Ostenvald, Germany. Another possible Portuguese representative of Pycnodus is reported from the Turonian of Bacarena, "Pycnodus" sp. aff. "P." gigas Jonet, 1964. However, the identification of the Portuguese specimens as Pycnodus are uncertain and the material most likely pertains to a different pycnodont taxon (Kriwet, 2001b). Isolated dentitions of what were claimed to be $P$. scrobiculatus, $P$. rostratus, and P. semilunaris from the Turonian of Czechoslovakia (Reuss, 1845) should be regarded as indeterminable pycnodontids due to the lack of characters useful to determine their affinities (Kriwet, 2001b). Isolated teeth attributed to "Pycnodus" lametae were reported from the Maastrichtian Lameta Formation of Dongargaon, India (Woodward, 1908). Infratrappean and intertrappean beds of Late Cretaceous and early Palaeocene age respectively, contains “P." lametae alongside Pycnodus sp. in Asifibad, India (Prasad \& Sahni, 1987).

Pycnodus is the most dominant taxon of the Palaeogene pycnodont assemblages being widely distributed in shallow water contexts worldwide. The earliest record of Pycnodus in the Palaeogene is represented by P. praecursor from the Danian of Angola (Dartevelle \& Casier, 1949) and P. sp. cf. P. praecursor from the Thanetian of Niger (Cappetta, 1972). P. toliapicus was reported from the Thanetian of Togo, Thanetian of Nigeria and the upper Palaeocene of Niger (White, 1934; Kogbe \& Wozny, 1979; Longbottom, 1984). Several remains of isolated dentitions and teeth from the Eocene have been attributed to Pycnodus. These include P. bicresta from the northwestern Himalayan region, India (Kumar \& Loyal, 1987; Prasad \& Singh, 1991); P. bowerbanki from the Ypresian, England, middle Eocene of Mali and Ypresian of Algeria (Longbottom, 1984; Savornin, 1915); Pycnodus sp. cf. P. toliapicus from the Eocene of Katar at the Persian Gulf (Casier, 1971); P. toliapicus from the Ypresian and Lutetian of England and Lutetian of the Paris basin and Belgium (Savornin, 1915; Casier, 1950; Taverne \& Nolf, 1978); P. mokattamensis from the Lutetian of Egypt (Priem, 1897); P. mokattamensis occurs alongside P. legrandi, P. lemellefensis, P. thamallulensis, P. vasseuri, and P. pellei from the Ypresian of Algeria (Savornin, 1915); P. pachyrhinus Grey-Egerton, 1877 from the Ypresian of Kent, England; P. funkianus Geinitz, 1883 from the Ypresian of Brunswick, Germany; P. munieri Priem, 1902 and P. savini Priem, 1902 from the Ypresian, France and a rather diverse assemblage from the middle Eocene of Mali which includes P. jonesae, P. maliensis, P. munieri, P. variablis, and P. zeaformis (Longbottom, 1984). 
A nearly complete specimen of $P$. lametae with crushed skull and missing caudal fin was reported from the freshwater Maastrichtian of Bhatali, India close to the Dongargaon area (Mohabey \& Udhoji, 1996). However, the assignment of the name Pycnodus to this fish is dubious, since it lacks the post-parietal process typical of the Pycnodontidae (J.J. Cawley, 2018, personal observation). A more complete specimen of Pycnodus was found in the Palaeocene rocks of Palenque, Mexico (Alvarado-Ortega et al., 2015), which differs from the Eocene specimens from Bolca by having a greater number of ventral and post-cloacal ridge scales, less dorsal- and anal-fin pterygiophores and a large or regular-sized posterior-most neural spine. However, due to the inadequacy of the available sample, it is not possible to determine the actual differences between the Palaeocene material from Mexico and that from the Eocene of Bolca, and for this reason this taxon is referred to as Pycnodus sp.

\section{MATERIAL AND METHODS}

\section{Specimen sampling}

We studied a selection of Pycnodus specimens from various museum collections, which were labeled either P. apodus, P. platessus, P. gibbus or Pycnodus sp. A total of 52 Pycnodus specimens from nine museum collections were used to obtain biometric information with 39 specimens from that sample being used for the geometric morphometric analysis as their higher quality preservation provided sufficient morphological information for the aim of this study (BM; Museo dei Fossili di Bolca; CM, Carnegie Museum, Pittsburgh, Pennsylvania; FMNH, Field Museum of Natural History, Chicago; MCSNV, Museo Civico di Storia Naturale di Verona; MGP-PD; Museo di Geologia e Paleontologia dell'Università di Padova; MNHN, Muséum National d'Histoire Naturelle, Paris; NHMUK, Natural History Museum of London; NHMW;

Naturhistorisches Museum Wien; SNSB-BSPG, Staatliche Naturwissenshaftliche Sammlungen Bayerns-Bayerische Staatssammlung für Paläontologie und Geologie, München, Germany). For this analysis, the sample includes 17 specimens identified originally as Pycnodus sp., 14 specimens as P. platessus, six specimens as P. gibbus, and two specimens as $P$. apodus.

\section{Geometric morphometric protocol}

A total of 18 landmarks, four anchor points, and 10 semi-landmarks were digitized on photos taken from the studied specimens in the corresponding collections using the software TPSdig (Rohlf, 2005). Landmarks indicating homologous points were selected on the basis of their possible ecological or functional role following the scheme applied in some studies (Claverie \& Wainwright, 2014; Tuset et al., 2014; Clarke, Lloyd \& Friedman, 2016; Marramà, Garbelli \& Carnevale, 2016a, 2016b; Marramà et al., 2016a; Marramà \& Carnevale, 2017) about shape variation in modern or extinct fishes (Fig. 1). The traits used match 12 out of 17 of the landmarks that was used for 57 species of Pycnodontiformes by Marramà et al. (2016a). Additional traits used here are the anterior and posterior margins of the cloaca to see if they shift significantly between morphotypes; using four landmarks around the orbit instead of one in the center to capture more 


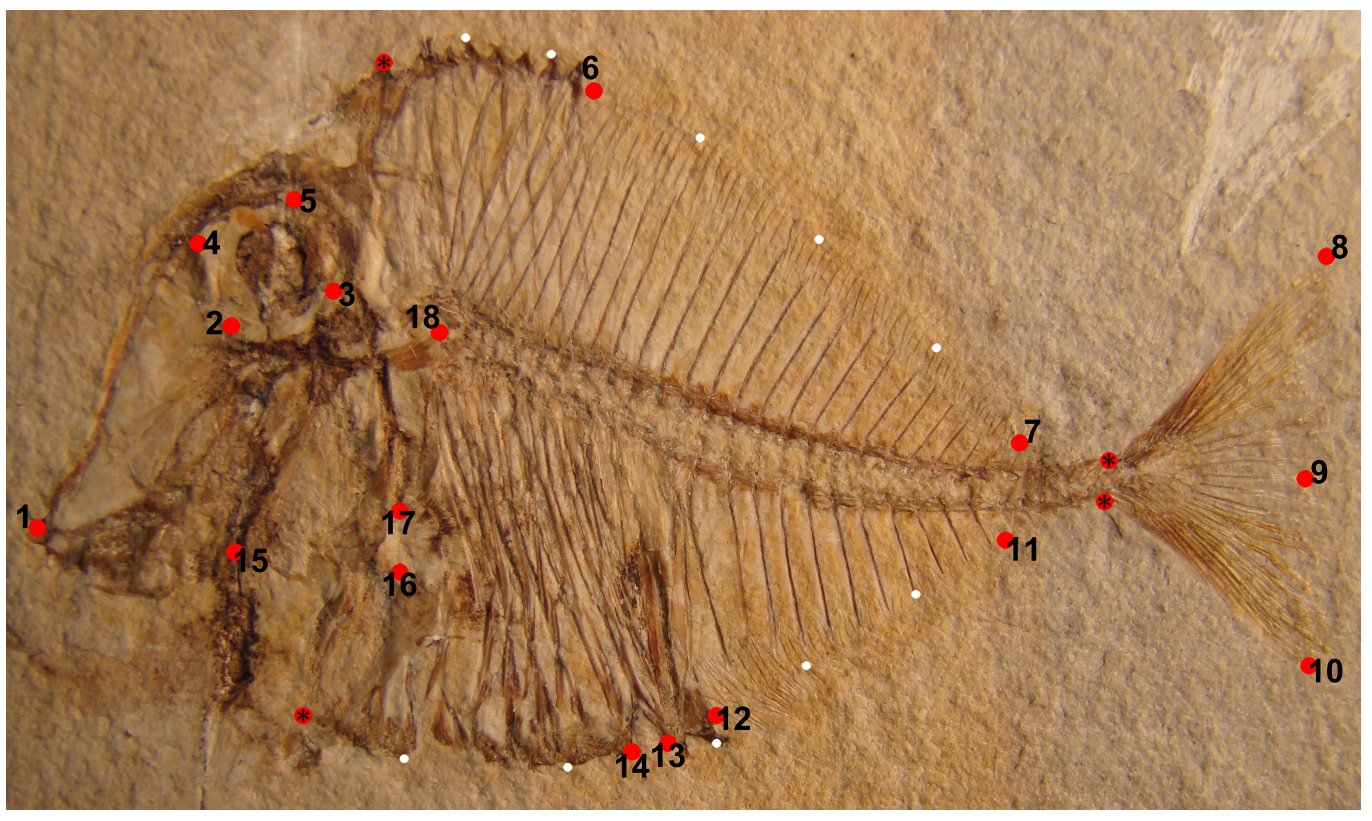

Figure 1 Landmarks represented by red circles, which were used on Pycnodus (MCSNV T.998) for the geometric morphometric analysis. These are (1) tip of premaxilla; (2) ventral-most margin of orbit; (3) posterior-most margin of orbit; (4) anterior-most margin of orbit; (5) dorsal-most margin of orbit; (6) first dorsal pterygiophore; (7) last dorsal pterygiophore; (8) tip of dorsal lobe of caudal fin; (9) medial convex margin of caudal fin; (10) tip of ventral lobe of caudal fin; (11) final anal pterygiophore; (12) first anal pterygiophore; (13) posterior cloacal scale; (14) anterior cloacal scale; (15) joint between quadrate and prearticular; (16) ventral-most concave margin of cleithrum accommodating pectoral fin; (17) dorsal-most concave margin of cleithrum accommodating pectoral fin; (18) Point of contact between neurocranium and vertebral column. Red circles marked with an asterisk are anchor points for the semi-landmarks. The semi-landmarks are represented by small white circles and are split into two sets; the first set consists of seven semi-landmarks between the tip of the dermosupraoccipital and the base of the first principal caudal fin ray; the second set has an additional seven semi-landmarks between the base of the ventral-most principal caudal fin ray and the antero-ventral corner of the cleithrum. Photo credit: Jürgen Kriwet. Full-size $\boldsymbol{\oplus}$ DOI: 10.7717 /peerj.4809/fig-1

precisely the variability surrounding the orbit; not using the insertion of the pelvic fin as this character was rarely preserved in our specimens; the use of two landmarks for the cleithrum to capture variability in position and size of the pectoral fin instead of using just the one landmark for the insertion of the first pectoral fin ray due to the poor preservation of the pectoral fins in many specimens in contrast to the concave notch in the cleithrum.

The landmark coordinates were translated, rotated and scaled at unit centroid size by applying a Generalized Procrustes Analysis (GPA) to minimize the variation caused by size, orientation, location and rotation (Rohlf \& Slice, 1990; Zelditch et al., 2004). The GPA was performed using the TPSrelw software package (Rohlf, 2003) and a principal component analysis was performed on Procrustes coordinates to obtain the Relative Warp (RW). Shape changes were shown along the axes using deformation grid plots. Missing values are replaced using the algorithm "Mean value imputation" (Hammer, Harper \& Ryan, 2001). 
Two non-parametric tests were performed to analyze the quantitative morphospace occupation of our Pycnodus specimens. In order to assess the degree of overlap between morphospaces, an analysis of similarities (ANOSIM) (Clarke, 1993) was performed on the entire dataset of standardized morphometric and meristic parameters. PERMANOVA (Anderson, 2001) was used to test similarities of in-group centroid position between the different groups representing a species of Pycnodus. Euclidean distances are the distance measure chosen for both tests. All statistical analyses were performed in PAST 3.18 (Hammer, Harper \& Ryan, 2001).

Since the studied specimens vary greatly in size (smallest being $4.0 \mathrm{~cm}$ and largest being $30.6 \mathrm{~cm}$ ) we also investigated whether size could be correlated with shape change in Pycnodus and enable us to see whether and how body shape changes throughout ontogeny. To analyze the relationship between size and shape, we performed a partial least square analysis (PLS) using the software TPSpls (Rohlf \& Corti, 2000). Alpha (level of significance) was set to 0.05 .

\section{Biometric analyses}

We used 11 meristic counts (number of vertebrae, ribs, scale bars, paired fin rays, median fin rays, median fin pterygiophores, caudal fin rays, and arcocentra interdigitations) and 19 measurements (see Supplementary Material) in order to capture morphological variability, to test the homogeneity of the sample, and confirming its assignment to a single morphotype. Histograms were used to illustrate the variation of morphometric and meristic data in order to ascertain if more than one morphotype of Pycnodus could be identified. Histograms can be problematic in accurately capturing the distribution of data (Salgado-Ugarte et al., 2000) so we also used Kernel density estimators to determine the presence of a normal (Gaussian) distribution of the meristic data. Least squares regression was used to obtain the relationship between standard length (SL) and all other morphometric variables. Specimens of possible additional taxa were indicated by the presence of statistical outliers from the regression line (Simon et al., 2010) and will require additional scrutiny in order to truly differentiate the outlier from all other specimens. The linear regression results were shown using scatterplots. Log-transformed data were used to perform the least squares regression in order to determine the degree of correlation between the SL and all other morphometric variables.

\section{RESULTS}

\section{Geometric morphometrics}

The RW analysis produced 38 RWs with the first three axes together explaining about 73\% of the total variation. Figures 2 and 3 show that there is significant overlap between the morphospaces of the Pycnodus taxonomic groups and the thin plate splines show the changes in shape along the axes. Negative values on RW1 (56.3\% explained) are related to Pycnodus specimens with large orbits and deep bodies while positive scores identify Pycnodus with reduced orbits and elongated bodies. Negative values of RW2 (10.3\% explained) show specimens having the pectoral fin with a wide base moved higher up the 


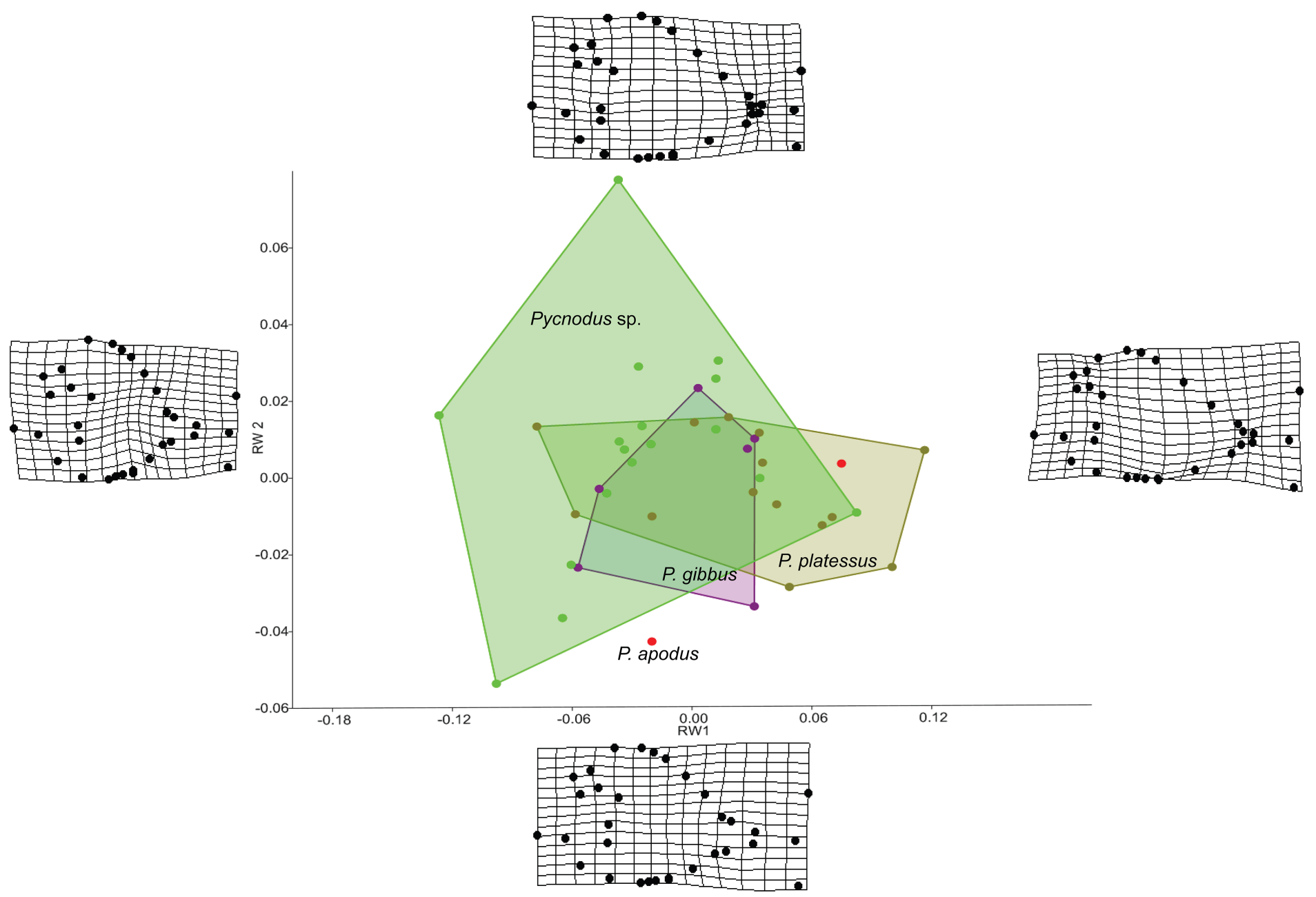

Figure 2 Morphospace of Pycnodus on the first two RW axes together accounting for about $66 \%$ of the overall shape variation. Deformation grids illustrate the shapes lying at extreme values along each axis.

Full-size $\underline{\bullet}$ DOI: $10.7717 /$ peerj.4809/fig-2

body alongside a long caudal peduncle (Fig. 2). Conversely, on positive scores of RW2 lie specimens with pectoral fin with a narrower base located more ventrally on the body alongside a small caudal peduncle. The negative values of RW3 (5.9\% explained) show the skull becoming deeper and more elongated with the dermosupraoccipital in particular reaching far back (Fig. 3). The body becomes shallower near the caudal peduncle with the cloaca shifting posteriorly, as well as the dorsal apex. Positive scores of RW3 are related to a shorter and shallower skull with the body becoming deeper close to the caudal peduncle and the anterior shift in the cloaca with the body becoming deeper just anterior to the cloaca. The dorsal apex shifts forward in position.

Analysis of similarities performed on the first three axes suggests that there is strong overlap between groups, showing they are barely distinguishable from each other ( $r$-value is 0.10 and $p>0.05$; see Table 1 ), except for a single pairwise comparison between Pycnodus sp. and P. platessus $(p<0.05)$. The PERMANOVA suggests the same trend (Table 2), showing that group centroids are not significantly different on each pairwise 

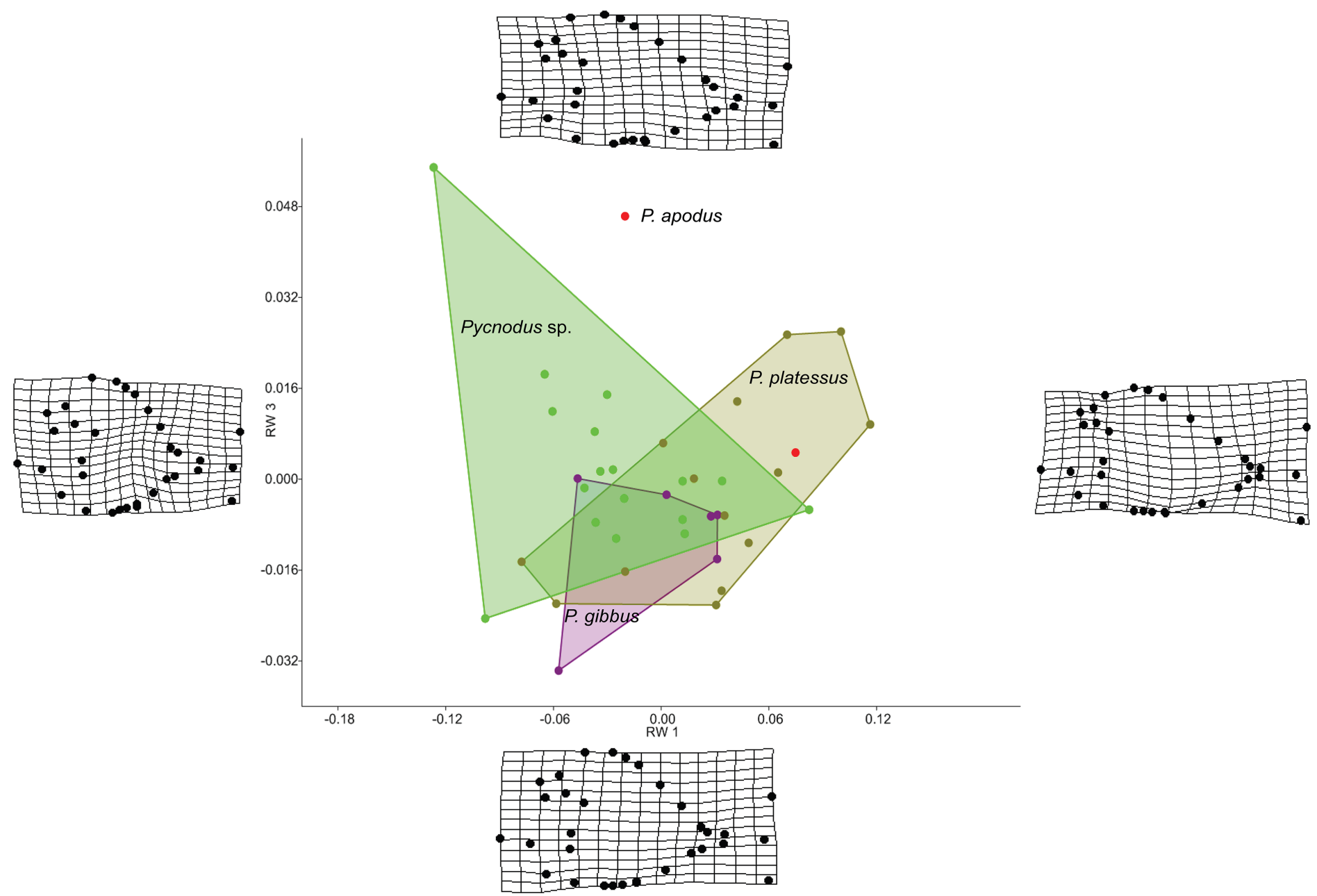

Figure 3 Morphospace of Pycnodus showing RW 1 on the $x$-axis and RW 3 on $y$-axis, the latter accounting for $6 \%$ of the overall shape variation. Deformation grids illustrate the shapes lying at extreme values along each axis. Full-size $\boldsymbol{\oplus}$ DOI: 10.7717 /peerj.4809/fig-3

Table 1 ANOSIM results.

\begin{tabular}{lllll} 
ANOSIM & P. apodus & P. gibbus & P. platessus & Pycnodus sp. \\
\hline P. apodus & 0 & 0.3583 & 0.7879 & 0.1717 \\
P. gibbus & 0.3583 & 0 & 0.3411 & 0.4755 \\
P. platessus & 0.7879 & 0.3411 & 0 & 0.0389 \\
Pycnodus sp. & 0.1717 & 0.4755 & 0.0389 & 0 \\
\hline
\end{tabular}

Note:

$r$-value is 0.10 and $p$-value is 0.06 .

comparison ( $f$-value is 2.83), except between Pycnodus sp. and P. platessus $(p<0.05)$ which lends significance to the overall $p$-value $(<0.05)$. Significant differences detected between Pycnodus sp. and P. platessus can be explained with the fact that the indeterminate Pycnodus specimens show a wide range of morphologies, with the extreme shapes ranging from negative to positive values of all the first three axes. 
Table 2 PERMANOVA results.

\begin{tabular}{lllll} 
PERMANOVA & P. apodus & P. gibbus & P. platessus & Pycnodus sp. \\
\hline P. apodus & 0 & 0.3228 & 0.5671 & 0.1586 \\
P. gibbus & 0.3228 & 0 & 0.2358 & 0.2876 \\
P. platessus & 0.5671 & 0.2358 & 0 & 0.0048 \\
Pycnodus sp. & 0.1586 & 0.2876 & 0.0048 & 0 \\
\hline
\end{tabular}

Note:

$f$-value is 2.83 and $p$-value is 0.03 .

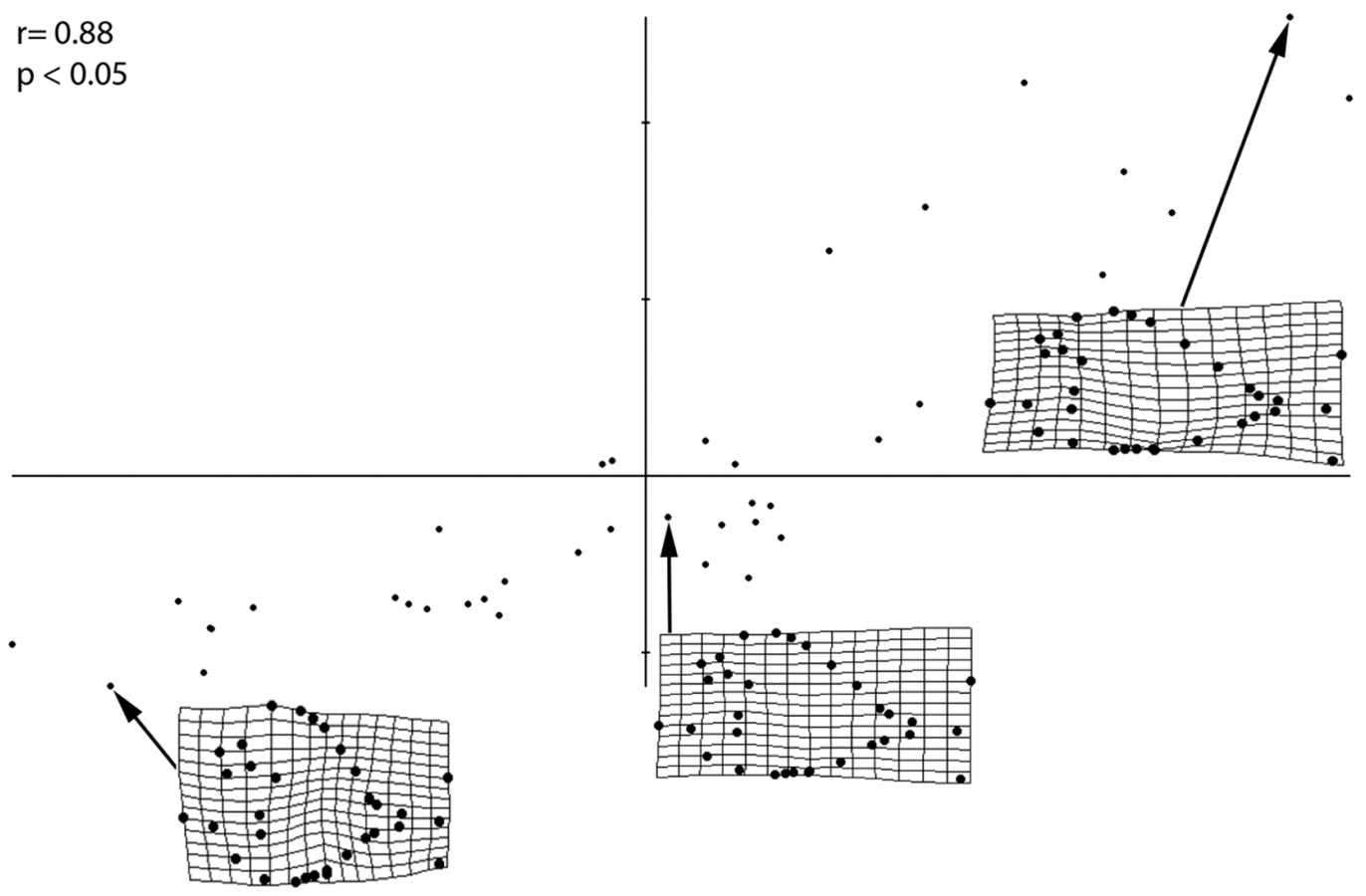

Figure 4 PLS analysis showing a correlation of morphometric variation with size. Smallest, medium sized, and largest specimens are used to represent the juvenile, small adult, and large adult stages, respectively. Significance of this correlation is shown by the $r$ and $p$-values. Smallest specimen is $4.02 \mathrm{~cm}$, medium sized specimen is $10.6 \mathrm{~cm}$, largest specimen is $30.6 \mathrm{~cm}$.

Full-size

The PLS performed on the entire sample (Fig. 4) revealed a strong and significant correlations between size and shape $(r=0.88 ; p<0.05)$, therefore suggesting that different shapes of the individuals are related to changes in shape of different ontogenetic stages. Small-sized individuals are associated with larger orbits, deeper skull and body shape, long skull, higher position of pectoral fin and a wide, indistinct caudal peduncle that is in distant proximity to both medial fins. Larger individuals, on the other hand, have a reduced orbit, shallower skull and body depth, shorter skull, lower position of pectoral fin and narrow caudal peduncle in close proximity to both medial fins. The PLS analysis therefore suggests that the morphological variations of the orbit, body depth and caudal peduncle are strongly related to ontogeny. 
Table 3 Measurements as percentage of SL (mean values in parentheses) used for identifying Pycnodus apodus.

Morphometric character Measurements in \% of SL

Head length $27.9-32.9(30.4)$

Head depth

48.5-57.7 (53.1)

Maximum body depth

$55.6-65.1(60.8)$

Pectoral fin base

6.5-9.2 (8.1)

Dorsal fin base

$37.4-44.3(40.9)$

Anal fin base

25.3-29.4 (27.8)

Caudal peduncle depth

3.8-5.1 (4.6)

Caudal peduncle length

13.6-15.7 (14.7)

Caudal fin span

$32.9-38.6(35.9)$

Prepectoral distance

28.1-30.7 (29.6)

Predorsal distance

$41.9-48.3(45.2)$

Prepelvic distance

48.6-52.7 (50.4)

Preanal distance

$56.9-60.3(58.6)$

Preorbital distance

9.9-14.4 (12.3)

Postorbital length

5.4-8.3 (7.1)

Orbit diameter

Note:

Range of measurements are represented by the 25th and 75th percentile.

Table 4 Mean meristic values used for identifying Pycnodus apodus.

\section{Meristic character}

Vertebrae

Rib pairs

Scale bars

Dorsal fin rays

Anal fin rays

Pectoral fin rays

Dorsal fin pterygiophores

Anal fin pterygiophores

Caudal fin rays

Note:

Range of meristic counts are represented by the 25th and 75th percentile. Mean meristic value in parentheses.

\section{Biometric analyses}

Morphometrics and meristic counts for all the studied specimens are given in Tables 3 and 4, respectively and mean biometric parameters are given in Table 5. Most of the histograms based on meristic counts (Fig. 5) do not show a normal (Gaussian) distribution due to the small sample size being unable to detect significant high frequency of mean values that might have suggested a Gaussian curve (De Baets, Klug \& Monnet, 2013), with intermediate states dominating and extreme states being rare. The linear 
Table 5 Mean morphometric and meristic data for the examined specimens of Pycnodus.

\begin{tabular}{|c|c|c|c|c|c|c|c|c|}
\hline Morphometric/meristic data & Min & $\operatorname{Max}$ & Mean & Median & Variance & $\begin{array}{l}\text { Standard } \\
\text { deviation }\end{array}$ & $\begin{array}{l}25 \text { th } \\
\text { percentile }\end{array}$ & $\begin{array}{l}75 \text { th } \\
\text { percentile }\end{array}$ \\
\hline Standard length & 2.9 & 27.7 & 11.1 & 8.8 & 46.7 & 6.8 & 5.9 & 16.4 \\
\hline Head length & 1.1 & 7.1 & 3.3 & 2.8 & 2.9 & 1.7 & 2.0 & 4.6 \\
\hline Head depth & 2.0 & 11.6 & 5.6 & 4.4 & 7.7 & 2.8 & 3.5 & 7.8 \\
\hline Maximum body depth & 2.1 & 13.4 & 5.8 & 4.9 & 8.4 & 2.9 & 3.8 & 7.4 \\
\hline Pectoral fin base & 0.2 & 1.8 & 0.8 & 0.7 & 0.2 & 0.4 & 0.5 & 1.1 \\
\hline Dorsal fin base & 1.1 & 12.5 & 4.9 & 3.7 & 10.5 & 3.2 & 2.4 & 6.3 \\
\hline Anal fin base & 0.7 & 9.6 & 3.4 & 2.5 & 5.6 & 2.4 & 1.6 & 5.0 \\
\hline Caudal peduncle depth & 0.2 & 1.2 & 0.5 & 0.4 & 0.1 & 0.3 & 0.3 & 0.6 \\
\hline Caudal peduncle length & 0.6 & 3.7 & 1.6 & 1.3 & 0.8 & 0.9 & 1.0 & 2.4 \\
\hline Caudal fin span & 0.9 & 10.7 & 4.1 & 3.0 & 6.7 & 2.6 & 2.2 & 6.9 \\
\hline Prepectoral distance & 1.1 & 7.2 & 3.1 & 2.8 & 2.5 & 1.6 & 1.9 & 4.0 \\
\hline Predorsal distance & 1.6 & 11.0 & 5.0 & 4.2 & 7.4 & 2.7 & 2.9 & 7.6 \\
\hline Prepelvic distance & 1.7 & 12.4 & 5.3 & 4.3 & 8.9 & 3.0 & 3.2 & 6.4 \\
\hline Preanal distance & 2.2 & 14.2 & 6.6 & 5.4 & 12.8 & 3.6 & 3.7 & 9.3 \\
\hline Preorbital distance & 0.3 & 4.1 & 1.4 & 1.1 & 1.0 & 1.0 & 0.8 & 1.9 \\
\hline Postorbital length & 0.3 & 1.7 & 0.7 & 0.6 & 0.1 & 0.3 & 0.5 & 0.8 \\
\hline Orbit diameter & 0.4 & 2.2 & 1.1 & 1.0 & 0.2 & 0.4 & 0.8 & 1.3 \\
\hline Lower jaw & 0.5 & 4.6 & 1.7 & 1.3 & 1.1 & 1.0 & 0.9 & 2.4 \\
\hline Vertebrae & 23 & 27 & 25.1 & 25 & 1.4 & 1.2 & 24 & 26 \\
\hline Rib pairs & 9 & 13 & 11.1 & 11 & 1.1 & 1.1 & 10 & 12 \\
\hline Scale bars & 7 & 11 & 8.7 & 8 & $0-9$ & 1.0 & 8 & 10 \\
\hline Dorsal fin rays & 46 & 66 & 56.4 & 56 & 18.2 & 4.3 & 54 & 60 \\
\hline Anal fin rays & 37 & 52 & 45.0 & 45 & 14.5 & 3.8 & 42 & 47.8 \\
\hline Pectoral fin rays & 24 & 47 & 35.2 & 35.5 & 43.9 & 6.6 & 30.3 & 39.8 \\
\hline Pelvic fin rays & 3 & 5 & 4.3 & 4 & 0.6 & 0.8 & 4 & 5 \\
\hline Dorsal fin pterygiophores & 38 & 65 & 55.8 & 57 & 30.5 & 5.5 & 52.8 & 60 \\
\hline Anal fin pterygiophores & 39 & 58 & 44.8 & 45 & 16.3 & 4.0 & 41 & 47 \\
\hline Caudal fin rays & 22 & 43 & 29.5 & 29 & 35.8 & 6.0 & 24.5 & 33.5 \\
\hline Arcocentra interdigitations & 2 & 3 & 2 & 2 & 0 & 0.2 & 2 & 2 \\
\hline
\end{tabular}

regression performed on morphometric characters (Fig. 6) shows that all specimens fit within the cloud of points near the regression line and that no particular specimens of Pycnodus deviates from this line. Variation in meristic values and the few outliers in partial least square regression analyses have been interpreted here as measurement errors due to incomplete preservation of some structures due to taphonomy or incomplete mineralization in juvenile individuals. The high values of the coefficient of determination $\left(r^{2}\right)$ ranging from 0.76 to 0.99 (Table 6) indicate a high degree of positive correlation between SL and each morphometric character. Linear regression analysis also revealed the highly significant relationship between the SL and all morphometric characters $(p<0.001)$. Neither morphometric nor meristic characters are therefore useful in determining two or more different morphologically identifiable species within Pycnodus, 
Peer」
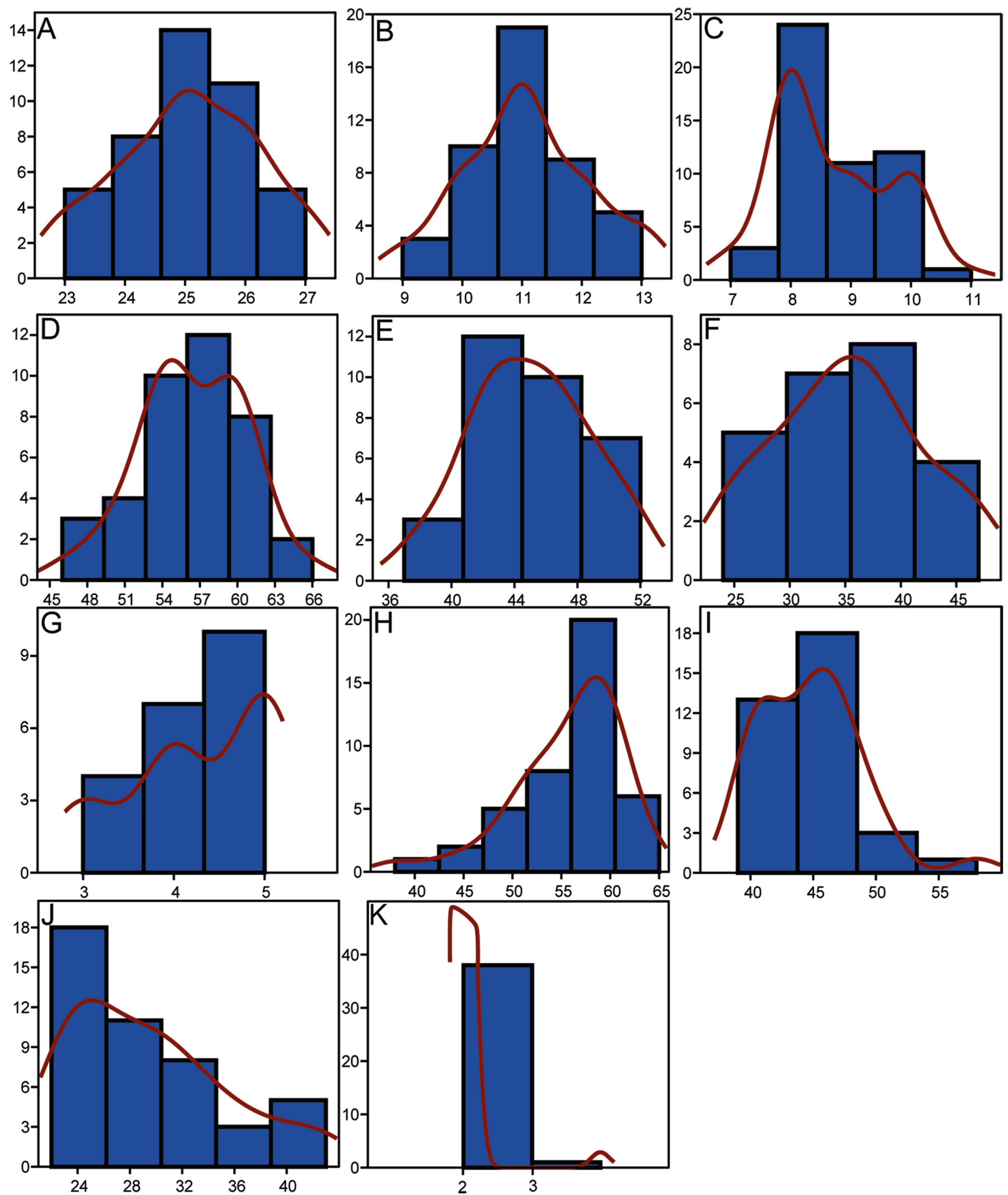
Figure 5 Histograms showing the distributions of meristic characters of Pycnodus. The $x$-axis represents the number of elements and the $y$-axis the relative frequency. Red curved line is the Kernel density estimator which measures the normality of each sample which reveals that there is a non-Gaussian distribution among all the samples. (A) Vertebrae. (B) Rib pairs. (C) Scale bars. (D) Dorsal fin rays. (E) Anal fin rays. (F) Pectoral fin rays. (G) Pelvic fin rays. (H) Dorsal fin pterygiophores. (I) Anal fin pterygiophores. (J) Caudal fin rays. (K) Arcocentra interdigitations.

Full-size

strongly supporting Blot's (1987) hypothesis that only one species (P. apodus; see also below) is present in the Bolca Lagerstätte.

\section{DISCUSSION}

\section{Intraspecific variation of Pycnodus apodus}

The results demonstrate that all Pycnodus species cannot be separated morphologically using the morphometric traits used herein in a quantitative approach, supporting the intraspecific variation hypothesis of Blot (1987). P. gibbus is a problematic taxon to identify due to Heckel (1856) not mentioning exactly which specimen he used to designate the specific name for P. gibbus. Blot (1987) mentions that Heckel worked on specimens from the NHMW in order to erect $P$. gibbus. However, such specimens could not be found and so the holotype still remains unknown. However, Heckel (1856, plate 8) does illustrate a specimen of $P$. gibbus and it conforms with what we have found to be the juvenile morphotype in our sample lending credence to the hypothesis by Agassiz (1833-1844) that the specimens he studied were specifically the juvenile of $P$. platessus. One of the characters separating P. gibbus from P. platessus (Heckel, 1856, plate 8, Fig. 4) is the number of interdigitations between vertebrae ( $P$. gibbus: two; P. platessus: three-four). However, a survey of the vertebral column of all our specimens reveals two to be the predominant number of interdigitations, including specimens labeled $P$. platessus and P. apodus. Apart from specimens where the degree of preservation was insufficient to do a count, only one specimen (MGP-PD 8868C) has three interdigitations which we ascertain to be due to intraspecific variation. Blot (1987, Table 6) also did not see any difference in the number of interdigitations between $P$. gibbus and P. platessus.

As suggested by Grande \& Young (2004), ontogenetic variation of morphological characters actually represents a primary source of intraspecific variation; this is confirmed by our analysis, specifically by the morphological changes mostly occurring along RW1 in the morphospace that are related to ontogeny and the very significant results deriving from the PLS analysis. The unimodal (Gaussian) distribution cannot be seen in most of the meristic data, as revealed by the Kernel density estimator on the frequency histograms (Fig. 5), due to the fact that the sample is too small to detect high frequency of mean values (De Baets, Klug \& Monnet, 2013). However, a few meristic characters reveal a domination of intermediate values and comparably rare extremes, which is typical of a homogenous population. Furthermore, the linear regression showed a significant dependence between SL and all morphometric variables, therefore suggesting that morphometric characters are not useful to distinguish different taxa. Meristic and morphometric data seem to show that all specimens studied belong to a single taxonomic entity (see Dagys, Bucher \& Weitschat, 1999; Dagys, 2001; Weitschat, 2008; Marramà \& Carnevale, 2015a; Sferco, López-Arbarello \& Báez, 2015). 

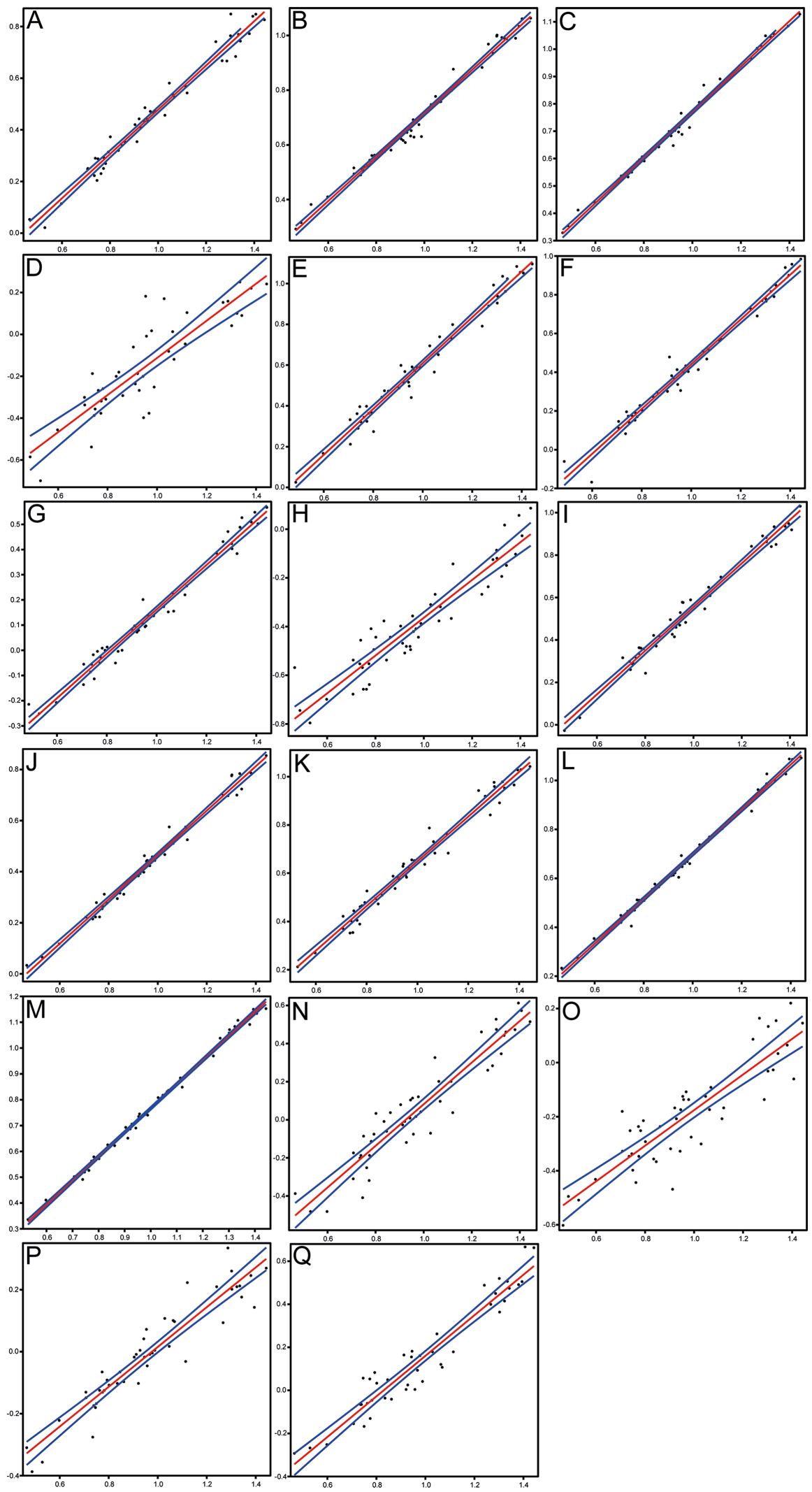
Figure 6 Scatterplots and regression lines with $95 \%$ confidence bands of the relationships between each morphometric character and the standard length of Pycnodus. (A) Head length. (B) Head depth. (C) Maximum body depth. (D) Pectoral fin base. (E) Dorsal fin base. (F) Anal fin base. (G) Caudal peduncle length. (H) Caudal peduncle depth. (I) Caudal fin span. (J) Prepectoral distance. (K) Predorsal distance. (L) Prepelvic distance. (M) Preanal distance. (N) Preorbital length. (O) Postorbital length. (P) Orbit diameter. (Q) Lower jaw length.

Full-size

Table 6 Relationships between morphometric characters and standard length using least squares regression for Pycnodus.

\begin{tabular}{llllllll} 
Variable character & $\begin{array}{l}\text { Slope } \\
\text { log }(\boldsymbol{y})\end{array}$ & $\begin{array}{l}\text { Intercept } \\
(\boldsymbol{b})\end{array}$ & $\begin{array}{l}\text { Coefficient of } \\
\text { determination }\left(\boldsymbol{r}^{2}\right)\end{array}$ & $\mathbf{9 5 \%}$ CI on $\boldsymbol{a}$ & 95\% CI on $\boldsymbol{b}$ \\
\hline Head length & 0.86 & -0.38 & 0.97 & 0.80 & 0.90 & -0.42 & -0.33 \\
Head depth & 0.80 & -0.09 & 0.98 & 0.77 & 0.83 & -0.11 & -0.06 \\
Maximum body depth & 0.83 & -0.06 & 0.99 & 0.81 & 0.85 & -0.08 & -0.04 \\
\hline Pectoral fin base & 0.89 & -1.00 & 0.76 & 0.77 & 0.99 & -1.11 & -0.88 \\
Dorsal fin base & 1.12 & -0.51 & 0.97 & 1.07 & 1.17 & -0.56 & -0.46 \\
Anal fin base & 1.16 & -0.71 & 0.97 & 1.09 & 1.22 & -0.78 & -0.64 \\
Caudal peduncle depth & 0.77 & -1.13 & 0.89 & 0.68 & 0.87 & -1.23 & -1.05 \\
Caudal peduncle length & 0.91 & -0.75 & 0.97 & 0.85 & 0.97 & -0.81 & -0.69 \\
Caudal fin span & 1.04 & -0.49 & 0.98 & 1.00 & 1.09 & -0.54 & -0.45 \\
Prepectoral distance & 0.87 & -0.40 & 0.98 & 0.83 & 0.90 & -0.43 & -0.36 \\
Predorsal distance & 0.91 & -0.26 & 0.98 & 0.86 & 0.95 & -0.30 & -0.21 \\
Prepelvic distance & 0.92 & -0.22 & 0.99 & 0.89 & 0.94 & -0.24 & -0.19 \\
Preanal distance & 0.93 & -0.17 & 0.99 & 0.91 & 0.95 & -0.19 & -0.14 \\
\hline Preorbital distance & 1.09 & -1.01 & 0.89 & 0.99 & 1.20 & -1.12 & -0.90 \\
\hline Postorbital length & 0.66 & -0.83 & 0.78 & 0.56 & 0.76 & -0.93 & -0.74 \\
\hline Orbit diameter & 0.64 & -0.63 & 0.89 & 0.57 & 0.71 & -0.69 & -0.56 \\
Lower jaw & 0.94 & -0.78 & 0.92 & 0.87 & 1.02 & -0.86 & -0.70 \\
\hline
\end{tabular}

Figure 7 shows some notable differences between the juvenile and larger specimens including the degree of ossification, particularly in the skull and caudal fin, being reduced in juvenile in comparison to adults and the notochord not being surrounded by arcocentra in juveniles whereas it is completely enclosed in adults. The so-called gibbosity that Heckel (1856) used to distinguish $P$. gibbus from P. platessus is formed by the angle of the anterior profile and the axis of the body. This angle decreases in larger specimens of Pycnodus from $70^{\circ}$ to $55^{\circ}$ (Blot, 1987) due to the skull roof moving posteriorly during growth revealing that this character probably does not denote a species but a growth stage within a single species. The high vertebrae length/body depth ratio said to be another indicator of $P$. gibbus is something that also decreases during growth. When Blot plotted all Pycnodus specimens onto a growth curve (Blot, 1987, fig. 32) P. gibbus fitted into the curve neatly on the lower end of the growth curve.

Differences in meristic counts (Table 7) are suggestive of intraspecific variation as seen in other fossil actinopterygians such as Sinamiidae from the Late Jurassic ( Su, 1973; Zhang \& Zhang, 1980) and Early Cretaceous (Stensiö, 1935); Palaeosconiformes from the Triassic (Lehman, 1952); Parasemionotidae from the Early Triassic (Olsen, 1984) 


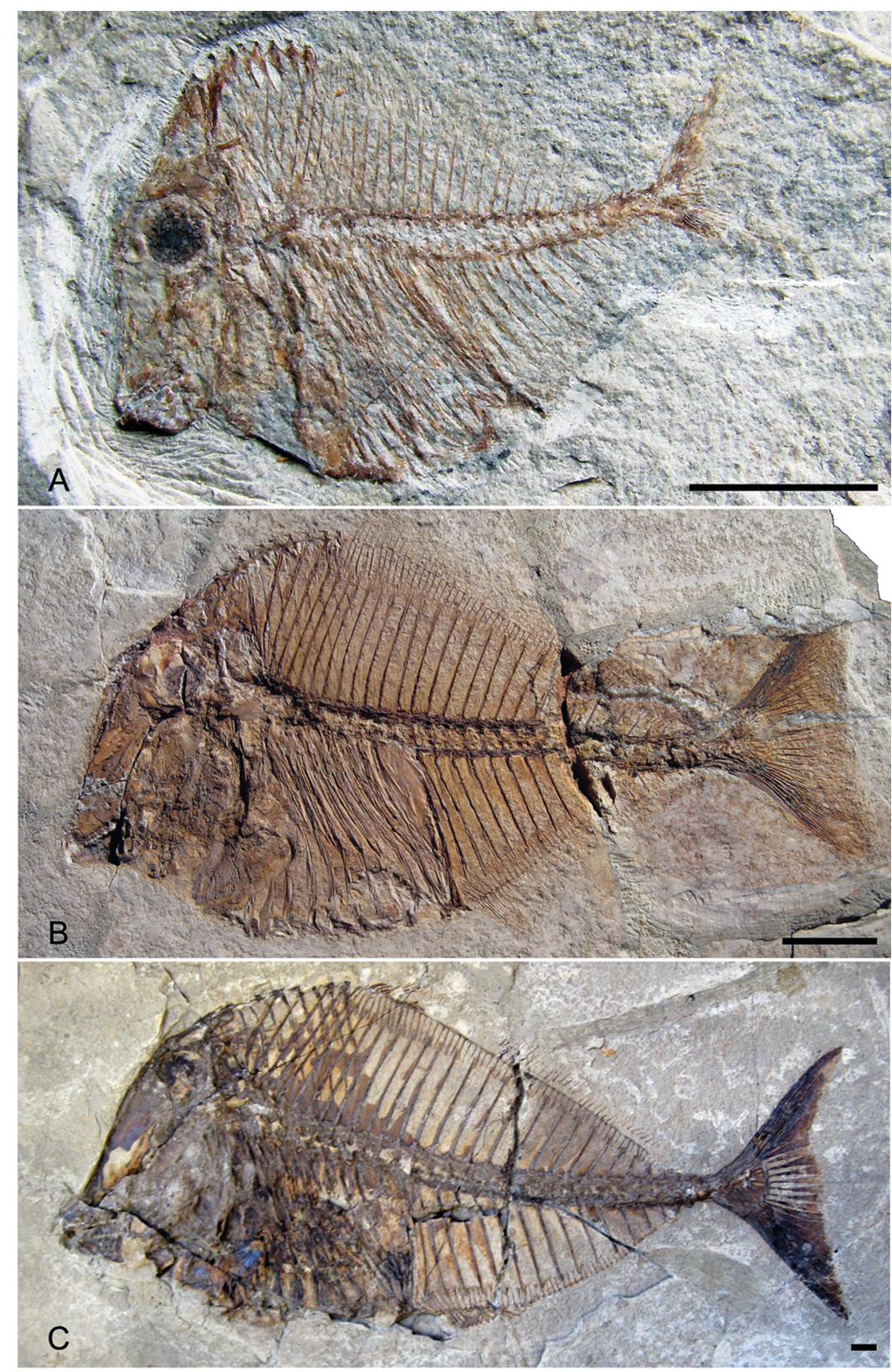

Figure 7 Ontogenetic series of Pycnodus. (A) Juvenile $4.02 \mathrm{~cm}$ (MCSNV T.309). (B) Small adult $13.25 \mathrm{~cm}$ (BSPG AS I 1208). (C) Large adult $30.61 \mathrm{~cm}$ (BSPG AS I 1209). Scale bar for all specimens equals $1 \mathrm{~cm}$. Photo credit: Jürgen Kriwet. Full-size DOI: $10.7717 /$ peerj.4809/fig-7

Teleosteomorpha from the Middle to Late Triassic (Tintori, 1990); Bobasatraniiformes from the Middle Triassic (Bürgin, 1992) Paramblypteidae from the Early Permian (Dietze, 1999, 2000) Dapediidae from the Early Jurassic (Thies \& Hauff, 2011); stem Actinopteri from the Middle Triassic (Xu, Shen \& Zhao, 2014); stem Teleostei from the Middle Triassic (Tintori et al., 2015); Pachycormiformes from the Early Jurassic (Wretman, Blom \& Kear, 2016); and the incertae sedis genus Teffichthys from the Early Triassic Marramà et al., 2017c). The analysis of the morphological variability of Pycnodus, 


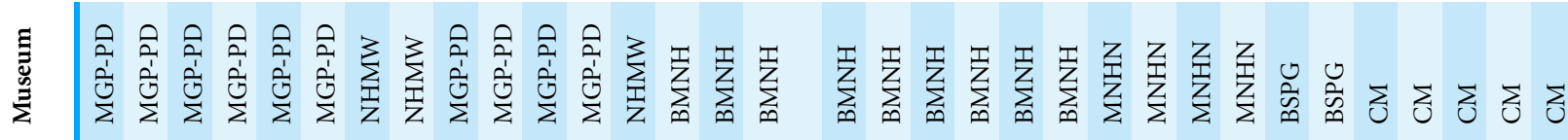

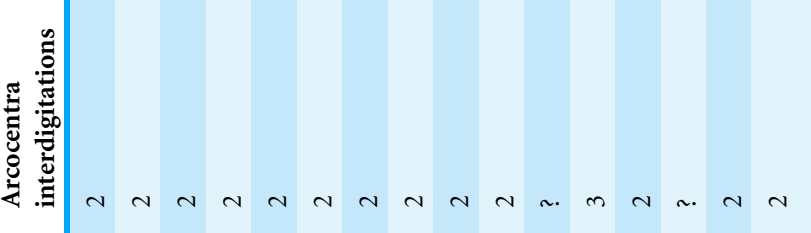

हूँ m

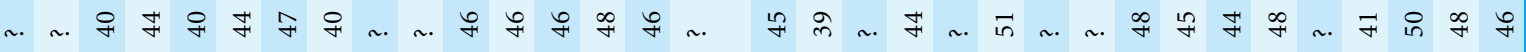

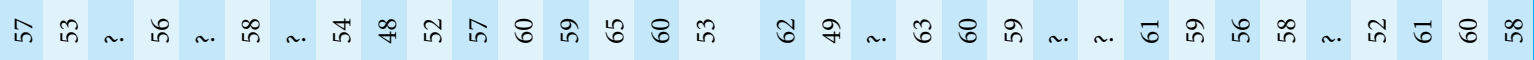
竞:

氙

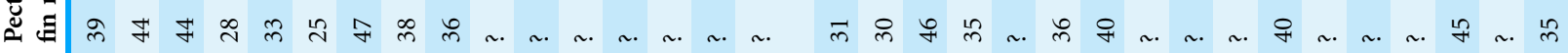
密焉

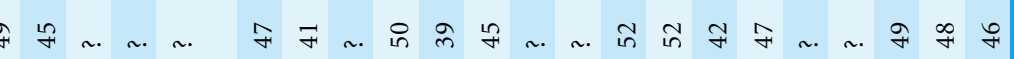

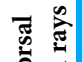

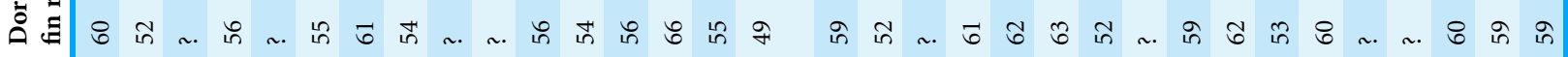

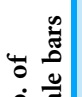

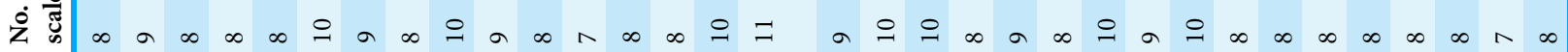

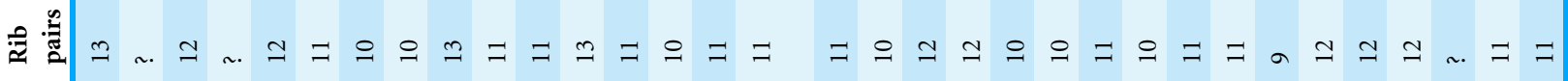

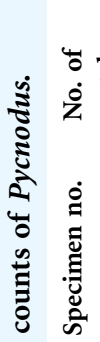

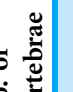

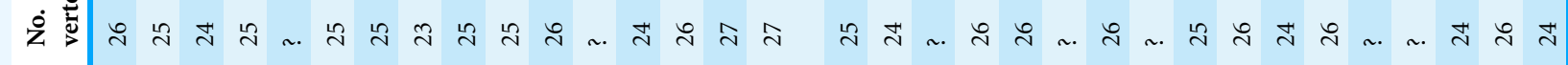

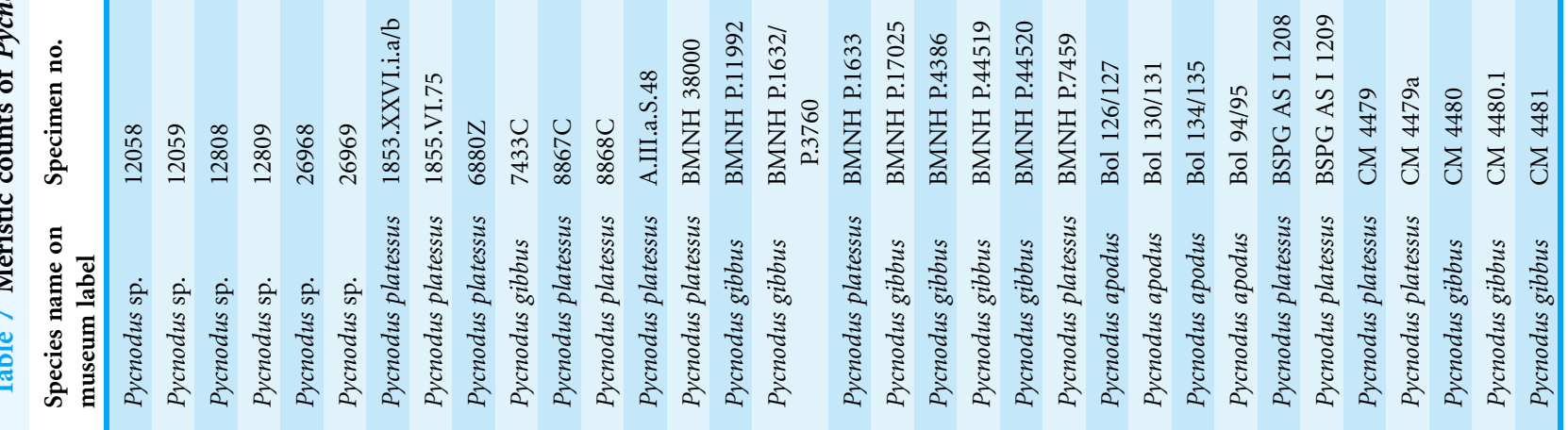




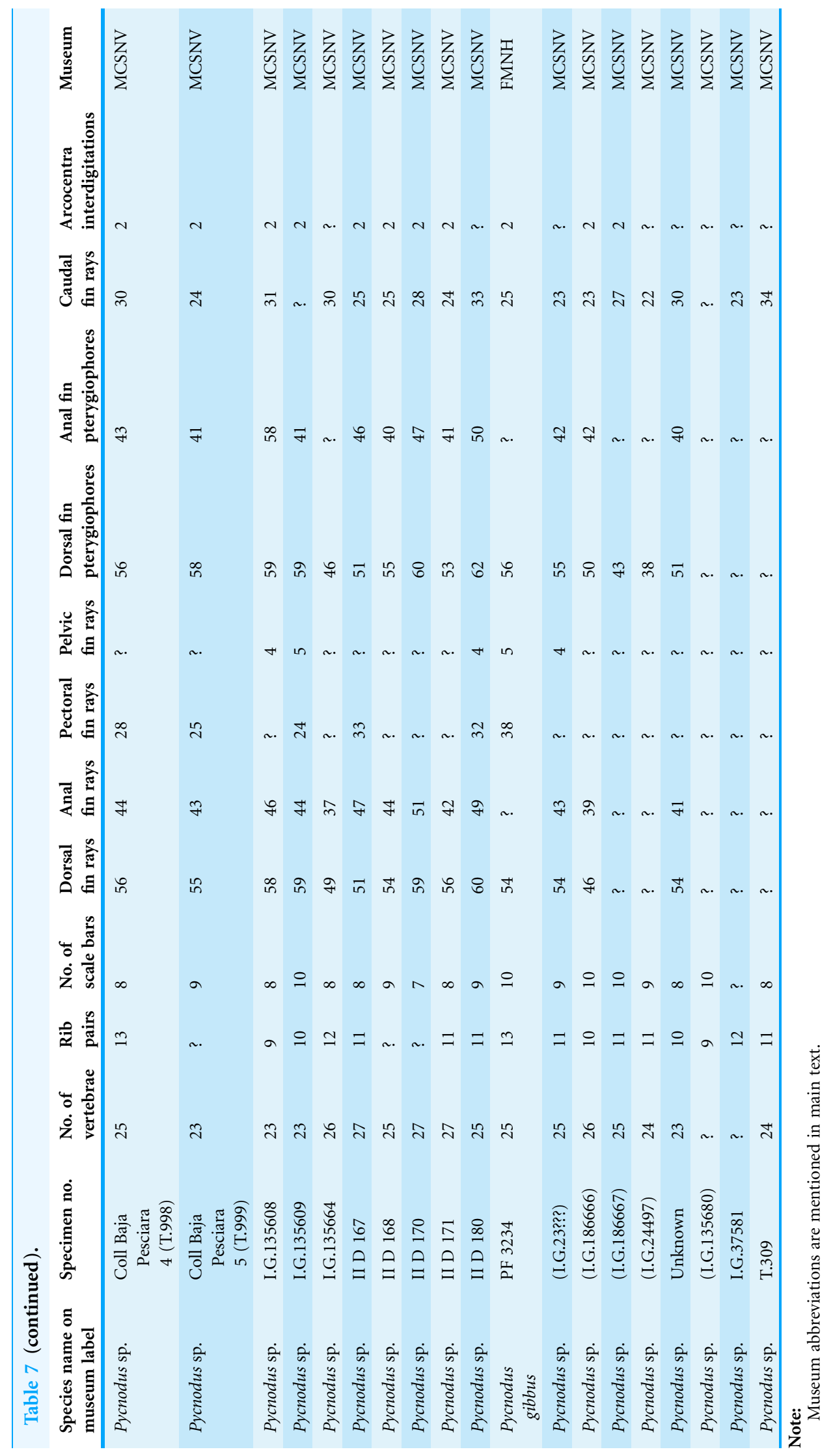


one of the last representatives of a basal neopterygian lineage that has been around since at least the Late Triassic (Tintori, 1981; Kriwet, 2001a; Poyato-Ariza, 2015), indicates that pycnodontiforms also produce substantial intraspecific variation similar to living representatives of other ancient actinopterygian lineages such as amiids (Jain, 1985) and acipenserids (Hilton \& Bemis, 1999). Therefore, the identification of different Bolca Pycnodus species such as P. gibbus (Heckel, 1856), may be the result of species oversplitting and can be on the contrary explained by intraspecific variation in meristic counts and ontogeny.

\section{Habitat use during ontogeny}

Our morphometric results show that the morphology of the smaller individuals differ significantly from that of the adults and that Pycnodus, like extant actinopterygians, would go through morphological changes throughout ontogeny. Large eye size found in the smaller Pycnodus specimens is usually a sign of the specimen being in a juvenile stage as can be seen in many extant teleosts (Pankhurst \& Montgomery, 1990). Large eye size in pycnodonts has been related to behavioral flexibility and possible nocturnal behavior (Goatley, Bellwood \& Bellwood, 2010). This could also apply for the Bolca Pycnodus although the individuals with the largest eyes (juveniles) are not believed to be more nocturnal as larger eye size in smaller fishes is a natural consequence of ontogeny. The deep body shape of the smaller Pycnodus specimens can be interpreted as a sign that the juveniles live within the branches of corals and as they get bigger they start to occupy the water column above the reef. Coral reefs composed of scleractinian coral colonies have been reported in situ (Vescogni et al., 2016) and were probably even more extensive based on abundant remains from the laminated and massive fossiliferous limestone from Pesciara and Monte Postale sites. This change to a benthopelagic lifestyle is also supported by the more fusiform body and the narrower caudal peduncle (Webb, 1982) seen in larger specimens.

Ecologically similar extant analogues to Pycnodus, fishes of the genus Lethrinus undergo ontogenetic changes in head shape as they grow in size but their body depth in relation to length does not change drastically during growth (Wilson, 1998). The sparid species Diplodus sargus and D. puntazzo also spend their time as juveniles in crevices in the rocks in shallow water 0-2 $\mathrm{m}$ deep and move to rocky bottoms and sea grass beds when adult (Macpherson, 1998). However, their ontogenetic trajectory differs from Pycnodus as they are more elongate as juveniles and body depth increases with age. Juvenile carangids also have a deeper body than that seen in adults (Leis et al., 2006) and are found within lagoonal patch reefs (Wetherbee et al., 2004) only moving out of this habitat when larger than $40 \mathrm{~cm}$ and becoming more pelagic in their habitat preferences (Kuiter, 1993; Myers, 1999). Eurasian perch (Perca fluviatilis) go through three different feeding modes during their life span; zooplanktivory, benthic macroinvertebrate feeding, and piscivory. The middle stage, benthic feeding results in them shifting to the littoral zone where they have a deeper body and longer fins which aid in maneuverability whereas piscivores and zooplanktivores have a similar body type due to both life stages living in the pelagic realm (Hjelm, Persson \& Christensen, 2000). 
Ontogenetically-related habitat changes also occur in other coral fishes, such as labrids, in which the pectoral fins increase their aspect ratio as these fishes grow in size, enabling them to increase their use of the water column while juveniles stay closer to the bottom (Fulton, Bellwood \& Wainwright, 2001). Since both juveniles and adults of Pycnodus are found in the Bolca Lagerstätte, we hypothesize that unlike many modern coral reef fishes, which significantly change the habitat during ontogeny (Nagelkerken et al., 2002; Dorenbosch et al., 2005a, 2005b; Adams et al., 2006; Nagelkerken, 2007; Nakamura et al., 2008; Shibuno et al., 2008; Kimirei et al., 2011), there is a shift instead in microhabitat use within the reef, in this case juveniles living within coral crevices to adults roaming over the coral reefs.

\section{CONCLUSION}

The quantitative approach here performed supports the hypothesis of Blot (1987) that the various P. nominal species ( $P$. apodus, . platessus, $P$. gibbus) from the Eocene Bolca Konservat-Lagerstätte actually belong to a single species. Due to the holotype of Pycnodus being given the specific name of apoda, all known specimens of Pycnodus from Bolca should be referred to as $P$. apodus. Most of the morphological variation can be explained by the close correlation between morphometric changes and ontogeny, with juveniles and adults occupying different parts of the morphospace. The morphometric differences between juveniles and adults may be due to occupation of different habitats with juveniles sheltering among cover and adults being better adapted to a roaming lifestyle swimming over the benthos to feed. The complex taxonomic history shows that most species typically referred to as Pycnodus are different taxa altogether (e.g. all Jurassic and Cretaceous Pycnodus specimens) and with the majority of Palaeogene Pycnodus being represented by isolated dentition it seems that the only definitive articulated skeletal remains attributed to the genus Pycnodus are P. apodus from the Bolca Lagerstätte and Pycnodus sp. from south-eastern Mexico (Alvarado-Ortega et al., 2015). Future studies should analyze other problematic

pycnodontiform taxa such as the widely distributed Gyrodus from the Middle Jurassic to the Early Cretaceous (Kriwet \& Schmitz, 2005) to investigate if intraspecific variation might partially explain the supposed diversity of species this genus contains.

\section{ACKNOWLEDGEMENTS}

We would like to thank M. Cerato (BM), Z. Johanson and E. Bernard (NHML), O. Rauhut (BSPG), A. Henrici (CM), L. Grande and W. Simpson (FMNH), M. Fornasiero (MGP-PD), A. Pradel and G. Clément (MNHN), A. Vaccari and R. Zorzin (MCSNV), and U. Göhlich (NHMW) for access to specimens and support while studying these specimens at the museum. We also are grateful to the helpful comments by the reviewers for improving the standard of this paper.

\section{ADDITIONAL INFORMATION AND DECLARATIONS}

\section{Funding}

This study was supported by a grant of the Austrian Science Fund (FWF): P29796-B29 to Jürgen Kriwet and M2368-B25 to Giuseppe Marramà, SYNTHESYS: FR-TAF-6568 to 
John Joseph Cawley. The funders had no role in study design, data collection and analysis, decision to publish, or preparation of the manuscript.

\section{Grant Disclosures}

The following grant information was disclosed by the authors:

Austrian Science Fund (FWF): P29796-B29 and M2368-B25.

SYNTHESYS: FR-TAF-6568.

\section{Competing Interests}

The authors declare that they have no competing interests.

\section{Author Contributions}

- John Joseph Cawley conceived and designed the experiments, performed the experiments, analyzed the data, prepared figures and/or tables.

- Giuseppe Marramà conceived and designed the experiments, performed the experiments, analyzed the data, contributed reagents/materials/analysis tools, authored or reviewed drafts of the paper, approved the final draft.

- Giorgio Carnevale authored or reviewed drafts of the paper, approved the final draft.

- Jürgen Kriwet conceived and designed the experiments, contributed reagents/materials/ analysis tools, authored or reviewed drafts of the paper, approved the final draft.

\section{Data Availability}

The following information was supplied regarding data availability:

The morphometric and landmark data for all the Pycnodus specimens studied are provided in the Supplemental Files.

\section{Supplemental Information}

Supplemental information for this article can be found online at http://dx.doi.org/ 10.7717/peerj.4809\#supplemental-information.

\section{REFERENCES}

Adams AJ, Dahlgren CP, Kellison GT, Kendall MS, Layman CA, Ley JA, Nagelkerken I, Serafy JE. 2006. Nursery function of tropical back-reef systems. Marine Ecology Progress Series 318:287-301 DOI 10.3354/meps318287.

Agassiz L. 1833. Synoptische Übersicht der fossilen Ganoiden. Neues Jahrbuch für Mineralogie, Geologie und Paläontologie 1833:470-481.

Agassiz L. 1833-1844. Recherches sur les Poissons Fossiles. Vol. 2. Neuchâtel: Petitpierre.

Alvarado-Ortega J, Cuevas-García M, del Pilar Melgarejo-Damián M, Cantalice KM, AlanizGalvan A, Solano-Templos G, Than-Marchese BA. 2015. Paleocene fishes from Palenque, Chiapas, southeastern Mexico. Palaeontologia Electronica 18:1-22 DOI 10.26879/536.

Anderson MJ. 2001. A new method for non-parametric multivariate analysis of variance. Austral Ecology 26(1):32-46 DOI 10.1111/j.1442-9993.2001.01070.pp.x.

Bannikov AF. 2004. Fishes from the Eocene of Bolca, northern Italy, previously classified with the Chaetodontidae (Perciformes). Studie Ricerche sui Giacimenti Terziari di Bolca 10:55-74. 
Bannikov AF. 2006. Fishes from the Eocene of Bolca, northern Italy, previously classified in the Sparidae, Serranidae and Haemulidae (Perciformes). Geodiversitas 28:249-275.

Bannikov AF. 2008. Revision of the atheriniform fish genera Rhamphognathus Agassiz and Mesogaster Agassiz (Teleostei) from the Eocene of Bolca, northern Italy. Studie Ricerche sui Giacimenti Terziari di Bolca 9:65-76.

Bannikov AF, Carnevale G. 2009. A new percoid fish from the Eocene of Monte Bolca, Italy: Hendrixella grandei gen. \& sp. nov. Swiss Journal of Geosciences 102(3):481-488 DOI 10.1007/s00015-009-1331-3.

Bannikov AF, Carnevale G. 2010. Bellwoodilabrus landinii, a new genus and species of labrid fish (Teleostei: Perciformes) from the Eocene of Monte Bolca. Geodiversitas 32(2):201-220 DOI 10.5252/g2010n2a2.

Bannikov AF, Carnevale G. 2016. Carlomonnius quasigobius gen. et sp. nov.: the first gobioid fish from the Eocene of Monte Bolca, Italy. Bulletin of Geosciences 91:13-22 DOI 10.3140/bull.geosci.1577.

Blainville HD. 1818. Sur les ichthyolithes ou les poissons fossiles. Nouveau Dictionnaire d'Histoire Naturelle, Deterville, Paris 27:310-395.

Blot J. 1987. L'ordre des Pycnodontiformes. Studi e Ricerche sui Giacimenti Terziari di Bolca V. L'ordre des Pycnodontiformes. Verona: Museo civico di storia Naturale.

Blot J, Tyler JC. 1990. New genera and species of fossil surgeon fishes and their relatives (Acanthuroidei, Teleostei) from the Eocene of Monte Bolca, Italy, with application of the Blot formula to both fossil and Recent forms. Studie Ricerche sui Giacimenti Terziari di Bolca 6:13-92.

Bürgin T. 1992. Basal ray-finned fishes (Osteichthyes; Actinopterygii) from the Middle Triassic of Monte San Giorgio (Canton Tessin, Switzerland). Schweizerische Paläontolologische Abhandlungen 114:1-164.

Cappetta H. 1972. Les poissons Crétacés et Tertiaires du bassin des Iullemmeden (République du Niger). Palaeovertebrata 5:179-251.

Carnevale G, Pietsch TW. 2009. An Eocene frogfish from Monte Bolca, Italy: the earliest skeletal record for the family. Palaeontology 52(4):745-752 DOI 10.1111/j.1475-4983.2009.00874.x.

Carnevale G, Pietsch TW. 2010. Eocene handfishes from Monte Bolca, with description of a new genus and species, and a phylogeny of the family Brachionichthyidae (Teleostei: Lophiiformes). Zoological Journal of the Linnean Society 160(4):621-647 DOI 10.1111/j.1096-3642.2009.00623.x.

Carnevale G, Pietsch TW. 2011. Batfishes from the Eocene of Monte Bolca. Geological Magazine 148(03):461-472 DOI 10.1017/s0016756810000907.

Carnevale G, Pietsch TW. 2012. †Caruso, a new genus of anglerfishes from the Eocene of Monte Bolca, Italy, with a comparative osteology and phylogeny of the teleost family Lophiidae. Journal of Systematic Palaeontology 10(1):47-72 DOI 10.1080/14772019.2011.565083.

Carnevale G, Bannikov AF, Marramà G, Tyler JC, Zorzin R. 2014. The Pesciara-Monte Postale Fossil-Lagerstätte: 2. Fishes and other vertebrates. Rendiconti della Società Paleontologica Italiana 4:37-63.

Carnevale G, Johnson GD, Marramà G, Bannikov AF. 2017. A reappraisal of the Eocene priacanthid fish Pristigenys substriata (De Blainville, 1818) from Monte Bolca, Italy. Journal of Paleontology 91(03):554-565 DOI 10.1017/jpa.2017.19.

Casier E. 1950. Contributions à l'étude des poissons fossiles de la Belgique. VIII. Les Pristidés éocènes. Bulletin du Musée Royal d'Histoire Naturelle de Belgique 25:1-52. 
Casier E. 1971. Sur un material ichthyologique des "Midra (and Saila) shales" du Qatar (Golfe Persique). Bulletin de l'Institut royal des Sciences naturelles de Belgique 47:1-9.

Cawley JJ, Kriwet J. 2018. A new pycnodont fish, Scalacurvichthys naishi gen. et sp. nov., from the Late Cretaceous of Israel. Journal of Systematic Palaeontology 16(8):659-673 DOI 10.1080/14772019.2017.1330772.

Clarke JT, Lloyd GT, Friedman M. 2016. Little evidence for enhanced phenotypic evolution in early teleosts relative to their living fossil sister group. Proceedings of the National Academy of Sciences of the United States of America 113:11531-11536 DOI 10.1073/pnas.1607237113.

Clarke KR. 1993. Non-parametric multivariate analysis of changes in community structure. Austral Ecology 18(1):117-143 DOI 10.1111/j.1442-9993.1993.tb00438.x.

Claverie T, Wainwright PC. 2014. A morphospace for reef fishes: elongation is the dominant axis of body shape evolution. PLOS ONE 9(11):e112732 DOI 10.1371/journal.pone.0112732.

Cope ED. 1886. A contribution to the vertebrate palaeontology of Brazil. Proceedings of the American Philosophical Society 23:1-21.

Coquand H. 1860. Synopsis des Animaux et des Végétaux Fossiles Observés dans les Formations Secondaires de la Charente, de la Charente-Inférieure et de la Dordogne. Marseille: BarlatierFeissat et Demonchy.

Cornuel J. 1883. Nouvelle note sur des Pycnodontes portlandiens et néocomiens de l'est du bassin de Paris, et sur des dents binaires de plusieurs d'entre eux. Bulletin de la Société géologique de France 11:18-27.

Cornuel MJ. 1886. Liste des fossiles du terrain crétacé inférieur de la Haute-Marne. Bulletin de la Société Géologique de France 14:312-323.

Costa OG. 1853. Paleontologia deI regno di Napoli. Atti della Accademia Pontaniana 1:1-380.

Costa OG. 1864. Paleontologia deI regno di Napoli, III. Atti Accademia Pontaniana 8:1-198.

Dagys AS. 2001. The ammonoid family Arctohungaritidae from the Boreal Lower-Middle Anisian (Triassic) of Arctic Asia. Revue de Paléobiologie 20:543-641.

Dagys AS, Bucher H, Weitschat W. 1999. Intraspecific variation of Parasibirites kolymensis Bychkov (Ammonoidea) from the Lower Triassic (Spathian) of Arctic Asia. Mitteilungen aus dem Geologisch-Paläontologischen der Institut Universität Hamburg 83:163-178.

Dartevelle E, Casier E. 1949. Les poissons fossiles du Bas-Congo et des régions voisines (deuxième partie). Annales du Musée du Congo Belge 3:201-256.

Davis JW. 1890. On the fossil fish of the Cretaceous formations of Scandinavia. Transactions of the Royal Dublin Society 4:363-434.

De Baets K, Klug C, Monnet C. 2013. Intraspecific variability through ontogeny in early ammonoids. Paleobiology 39(01):75-94 DOI 10.1666/0094-8373-39.1.75.

Dietze K. 1999. Paramblypterus duvernoyi (Actinopterygii): skull morphology and intra-specific variation, and its implications for the systematics of paramblypterid fishes. Journal of Vertebrate Paleontology 19(2):247-262 DOI 10.1080/02724634.1999.10011139.

Dietze K. 2000. A revision of paramblypterid and amblypterid actinopterygians from Upper Carboniferous-Lower Permian lacustrine deposits of central Europe. Palaeontology 43(5):927-966 DOI 10.1111/1475-4983.00156.

Dorenbosch M, Grol MGG, Christianen MJA, Nagelkerken I, van der Velde G. 2005a. IndoPacific seagrass beds and mangroves contribute to fish density coral and diversity on adjacent reefs. Marine Ecology Progress Series 302:63-76. 
Dorenbosch M, Grol MGG, Nagelkerken I, van der Velde G. 2005b. Distribution of coral reef fishes along a coral reef-seagrass gradient: edge effects and habitat segregation. Marine Ecology Progress Series 299:277-288 DOI 10.3354/meps299277.

d'Erasmo G. 1914. La fauna e l'età dei calcari a ittioliti di Pietraroia (Prov. Di Benevento). Palaeontographica Italica 20:29-86.

Egerton P. 1855. Pycnodus liassicus. Memoirs of the Geological Survey of the United Kingdom. British Organic Remains, Decade VIII:1-3.

Forir H. 1887. Contributions à l'étude du système Crétacé de la Belgique. 1: Sur quelques poissons et crustacés nouveaux ou mal connus. Annales de la Société Géologique de Belgique 14:25-56.

Fulton C, Bellwood D, Wainwright P. 2001. The relationship between swimming ability and habitat use in wrasses (Labridae). Marine Biology 139(1):25-33 DOI 10.1007/s002270100565.

Geinitz HB. 1883. Ueber neue Funde in den Phosphatlagern von Helmstedt, Büddenstedt und Schleweke. Abhandlungen der Gesellschaft Isis 5:37-46.

Goatley CHR, Bellwood DR, Bellwood O. 2010. Fishes on coral reefs: changing roles over the past 240 million years. Paleobiology 36(03):415-427 DOI 10.1666/09035.1.

Goodwin MB, Clemens WA, Hutchison JH, Wood CB, Zavada MS, Kemp A, Duffin CJ, Schaff CR. 1999. Mesozoic continental vertebrates with associated palynostratigraphic dates from the northwestern Ethiopian. Journal of Vertebrate Paleontology 19(4):728-741 DOI 10.1080/02724634.1999.10011185.

Grande T, Young B. 2004. The ontogeny and homology of the Weberian apparatus in the zebrafish Danio rerio (Ostariophysi: Cypriniformes). Zoological Journal of the Linnean Society 140(2):241-254 DOI 10.1111/j.1096-3642.2003.00097.x.

Grey-Egerton P. 1877. On some new pycnodonts. Geological Magazine 4(02):49-55 DOI $10.1017 /$ s0016756800148563.

Hammer Ø, Harper DAT, Ryan PD. 2001. PAST: paleontological statistics software package for education and data analysis. Palaeontologia Electronica 4:1-9.

Heckel J. 1854. Über den Bau und die Eintheilung der Pycnodonten, nebst kurzer Beschreibung einiger neuen Arten derselben. Sitzungsberichte der Kaiserlichen Akademie der Wissenschaften, Mathematisch-Naturwissenschafliche Klasse 12:433-464.

Heckel J. 1856. Beiträge zur Kenntnis der fossilen Fische erreichs. Denkschriften der Kaiserlischen Akademie der Wissenschaften Mathematisch-Naturwissenschaftliche Classe 11:187-274.

Hilton EJ, Bemis WE. 1999. Skeletal variation in shortnose sturgeon (Acipenser brevirostrum) from the Connecticut River: Implications for comparative osteological studies of fossil and living fishes. In: Arratia G, Schultze HP, eds. Mesozoic Fishes 2-Systematics and Fossil Record. Munich: Verlag Dr. F. Pfeil, 69-94.

Hjelm J, Persson L, Christensen B. 2000. Growth, morphological variation and ontogenetic niche shifts in perch (Perca fluviatilis) in relation to resource availability. Oecologia 122(2):190-199 DOI 10.1007/pl00008846.

Jain SL. 1985. Variability of dermal bones and other parameters in the skull of Amia calva. Zoological Journal of the Linnean Society 84(4):385-395 DOI 10.1111/j.1096-3642.1985.tb01805.x.

Jonet S. 1964. Contribution à la connaissance de la faune ichthyologique crétacée. II-Élements de la faune turonnienne. Boletim da Sociedade Geológica de Portugal 15:157-174.

Kimirei IA, Nagelkerken I, Griffioen B, Wagner C, Mgaya YD. 2011. Ontogenetic habitat use by mangrove/seagrass-associated coral reef fishes shows flexibility in time and space. Estuarine Coastal and Shelf Science 92(1):47-58 DOI 10.1016/j.ecss.2010.12.016. 
Kogbe CA, Wozny E. 1979. Upper Maastrichtian and Paleocene macrofauna from the Iullemmeden Basin (West Afrika) and their paleobiogeographic distribution. Annals of the Geology Survey of Egypt 9:184-218.

Kriwet J. 2001a. Palaeobiogeography of pycnodontiform fishes (Actinopterygii, Neopterygii). Seminario de Paleontología de Zaragoza 5(1):121-130.

Kriwet J. 2001b. A comprehensive study of pycnodont fishes (Neopterygii, Pycnodontiformes): Morphology, Taxonomy, Functional Morphology, Phylogeny, and Palaeobiogeography. D. Phil thesis, Humboldt University.

Kriwet J. 2005. A comprehensive study of the skull and dentition of pycnodont fishes (Neopterygii, Pycnodontiformes). Zitteliana 45:135-188.

Kriwet J, Schmitz L. 2005. New insight into the distribution and palaeobiology of the pycnodont fish Gyrodus. Acta Palaeontologica Polonica 50:49-56.

Kuiter RH. 1993. Coastal Fishes of South-Eastern Australia. Bathurst: Crawford House.

Kumar K, Loyal RS. 1987. Eocene ichthyofauna from the Subathu Formation, northwestern Himalaya, India. Journal of the Palaeontological Society of India 32:60-84.

Lehman JP. 1952. Etude complémentaire des poissons de l'Eotrias de Madagascar. Kungliga Svenska Vetenskaps Akademiens Handlingar 4:1-201.

Leis JM, Hay AC, Clark DL, Chen IS, Shao KT. 2006. Behavioral ontogeny in larvae and early juveniles of the giant trevally (Caranx ignobilis) (Pisces: Carangidae). Fishery Bulletin 104:401-414.

Longbottom AE. 1984. New Tertiary pycnodonts from the Tilemsi valley, Republic of Mali. Bulletin of the British Museum of Natural History 38:1-26.

Macpherson E. 1998. Ontogenetic shifts in habitat use and aggregation in juvenile sparid fishes. Journal of Experimental Marine Biology and Ecology 220(1):127-150 DOI 10.1016/s0022-0981(97)00086-5.

Marramà G, Carnevale G. 2015a. The Eocene sardine $†$ Bolcaichthys catopygopterus (Woodward, 1901) from Bolca, Italy: osteology, taxonomy and paleobiology. Journal of Vertebrate Paleontology 35(6):e1014490 DOI 10.1080/02724634.2015.1014490.

Marramà G, Carnevale G. 2015b. Eocene round herring from Monte Bolca, Italy. Acta Palaeontologica Polonica 60:701-710 DOI 10.4202/app.00057.2014.

Marramà G, Carnevale G. 2016. An Eocene anchovy from Monte Bolca, Italy: the earliest known record for the family Engraulidae. Geological Magazine 153(01):84-94 DOI 10.1017/s0016756815000278.

Marramà G, Carnevale G. 2017. Morphology, relationships, and paleobiology of the Eocene barracudina $\dagger$ Holosteus esocinus (Aulopiformes, Paralepididae) from Monte Bolca, Italy. Zoological Journal of the Linnean Society 181(1):209-228 DOI 10.1093/zoolinnean/zlw029.

Marramà G, Garbelli C, Carnevale G. 2016a. A morphospace for the Eocene fish assemblage of Bolca, Italy: a window into the diversification and ecological rise to dominance of modern tropical marine fishes. Bollettino della Società Paleontologica Italiana 55:11-21

DOI 10.4435/BSPI.2016.02.

Marramà G, Garbelli C, Carnevale G. 2016b. A clade-level morphospace for the Eocene fishes of Bolca: patterns and relationships with modern tropical marine fish assemblages. Bollettino della Società Paleontologica Italiana 55:139-156 DOI 10.4435/BSPI.2016.13.

Marramà G, Villier B, Dalla Vecchia FM, Carnevale G. 2016a. A new species of Gladiopycnodus (Coccodontoidea, Pycnodontomorpha) from the Cretaceous of Lebanon provides new insights 
about the morphological diversification of pycnodont fishes through time. Cretaceous Research 61:34-43 DOI 10.1016/j.cretres.2015.12.022.

Marramà G, Bannikov AF, Tyler JC, Zorzin R, Carnevale G. 2016b. Controlled excavations in the Eocene Pesciara and Monte Postale deposits reveal new details about the paleoecology and taphonomy of the fish assemblages of Bolca Konservat-Lagerstätte, Italy. Palaeogeography, Palaeoclimatology, Palaeoecology 454:228-245 DOI 10.1016/j.palaeo.2016.04.021.

Marramà G, Claeson KM, Carnevale G, Kriwet J. 2017a. Revision of Eocene electric rays (Torpediniformes, Batomorphii) from the Bolca Konservat-Lagerstätte, Italy, reveals the first fossil embryo in situ in marine batoids and provides new insights into the origin of trophic novelties in coral reef fishes. Epub ahead of print 21 September 2017. Journal of Systematic Palaeontology DOI 10.1080/14772019.2017.1371257.

Marramà G, Engelbrecht A, Carnevale G, Kriwet J. 2017b. Eocene sand tiger sharks (Lamniformes, Odontaspididae) from the Bolca Konservat-Lagerstätte, Italy: palaeobiology, palaeobiogeography and evolutionary significance. Historical Biology 2017:1-15 DOI 10.1080/08912963.2017.1341503.

Marramà G, Lombardo C, Tintori A, Carnevale G. 2017c. Redescription of 'Perleidus' (Osteichthyes, Actinopterygii) from the Early Triassic of northwestern Madagascar. Rivista Italiana di Paleontologia e Stratigrafia 123:219-242 DOI 10.13130/2039-4942/8328.

Mohabey DM, Udhoji SG. 1996. Pycnodus lametae (Pycnodontidae), a holostean fish from freshwater Upper Cretaceous Lameta Formation of Maharashtra. Journal of the Geological Society of India 47:593-598.

Myers RF. 1999. Mirconesian Reef Fishes. A Comprehensive Guide to the Coral Reef Fishes of Micronesia. Guam: Coral Graphics.

Nagelkerken I. 2007. Are non-estuarine mangroves connected to coral reefs through fish migration? Bulletin of Marine Science 80:595-607.

Nagelkerken I, Roberts CM, van der Velde G, Dorenbosch M, van Riel MC, Cocheret de la Moriniere E, Nienhuis PH. 2002. How important are mangroves and seagrass beds for coralreef fish? The nursery hypothesis tested on an island scale. Marine Ecology Progress Series 244:299-305 DOI 10.3354/meps244299.

Nakamura Y, Horinouchi M, Shibuno T, Tanaka Y, Miyajima T, Koike I, Kurokura H, Sano M. 2008. Evidence of ontogenetic migration from mangroves to coral reefs by black-tail snapper Lutjanus fulvus: stable isotope approach. Marine Ecology Progress Series 355:257-266 DOI 10.3354/meps07234.

Olsen PE. 1984. The skull and pectoral girdle of the parasemionotid fish Watsonulus eugnathoides from the Early Triassic Sakamena Group of Madagascar, with comments on the relationships of the holostean fishes. Journal of Vertebrate Paleontology 4(3):481-499 DOI 10.1080/02724634.1984.10012024.

Pankhurst NW, Montgomery JC. 1990. Ontogeny of vision in the Antarctic fish Pagothenia borchgrevinki (Nototheniidae). Polar Biology 10(6):419-422 DOI 10.1007/bf00233689.

Papazzoni CA, Carnevale G, Fornaciari E, Giusberti L, Trevisani E. 2014. The Pesciara-Monte Postale Fossil-Lagerstätte: 1. Biostratigraphy, sedimentology and depositional model. Bolca Fossil-Lagerstätte: A Window into the Eocene World: Rendiconti della Società Paleontologica Italiana 4:29-36.

Pictet FJ, Campiche G, de Tribolet G. 1858-60. Description des fossiles du terrain Crétacé des environs de Sainte-Croix. Première Partie. Genève: J. Kessmann \& H. Georg. 
Poyato-Ariza FJ. 2005. Pycnodont fishes: morphologic variation, ecomorphologic plasticity, and a new interpretation of their evolutionary history. Bulletin of the Kitakyushu Museum of Natural History and Human History 3:169-184.

Poyato-Ariza FJ. 2013. Sylvienodus, a new replacement genus for the Cretaceous pycnodontiform fish "Pycnodus" laveirensis. Comptes Rendus Palevol 12(2):91-100

DOI 10.1016/j.crpv.2013.01.001.

Poyato-Ariza FJ. 2015. Studies on pycnodont fishes (I): evaluation of their phylogenetic position among actinopterygians. Rivista Italiana di Paleontologia e Stratigrafia 121:329-343 DOI 10.13130/2039-4942/6521.

Poyato-Ariza FJ, Wenz S. 2002. A new insight into pycnodontiform fishes. Geodiversitas 24:139-248.

Poyato-Ariza FJ, Talbot MR, Fregenal-MartInez MA, Melendez N, Wenz S. 1998. First isotopic and multidisciplinary evidence for nonmarine coelacanths and pycnodontiform fishes: palaeoenvironmental implications. Palaeogeography Palaeoclimatology Palaeoecology 144(1-2):65-84 DOI 10.1016/s0031-0182(98)00085-6.

Prasad GVR, Sahni A. 1987. Coastal-plain microvertebrate assemblage from the terminal Cretaceous of Asifabad, Peninsular India. Journal of the Palaeontological Society of India 32:5-19.

Prasad GVR, Singh V. 1991. Microvertebrates from the Infiatrappean Beds of Rangareddi District, Andhra Pradesh and their biostratigraphic significance. Bulletin of the Indian Geologists' Association 24:1-20.

Priem F. 1897. Sur les poissons de l'Éocène du Mont Mokattam (Égypte). Bulletin de la Société géologique de France 25:212-227.

Priem F. 1902. Sur des pycnodontes tertiaires du departement de l'Aude. Bulletin de la Société géologique de France 10:44-49.

Reuss A. 1845. Die Versteinerungen der Bohmischen Kreideformationen. Stuttgart: Schweitzerbart.

Roemer FA. 1841. Die Versteinerungen des Norddeutschen Kreidegebirges. Hannover: Hahn'sche Hofbuchhandlung.

Rohlf FJ. 2003. TpsRelw, relative warps analysis. Version 1.36. State University of New York at Stony Brook: Department of Ecology and Evolution. Available at http://life.bio.sunysb.edu/morph/.

Rohlf FJ. 2005. TpsDig, digitize landmarks and outlines. Version 2.05. State University of New York at Stony Brook: Department of Ecology and Evolution. Available at life.bio.sunysb.edu/morph/.

Rohlf FJ, Slice DE. 1990. Extensions of the Procrustes method for the optimal superimposition of landmarks. Systematic Biology 39(1):40-59 DOI 10.2307/2992207.

Rohlf FJ, Corti M. 2000. Use of two-block partial least-squares to study covariation in shape. Systematic Biology 49(4):740-753 DOI 10.1080/106351500750049806.

Salgado-Ugarte IH, Shimizu M, Taniuchi T, Matsushita K. 2000. Size frequency analysis by averaged shifted histograms and kernel density estimators. Asian Fisheries Science 13:1-12.

Sauvage HE. 1880. Synopsis des poissons et des reptiles des terrains jurassiques de Boulognesur-Mer. Bulletin de la Société géologique de France 8:524-547.

Sauvage HE. 1893. Note sur quelques poissons du calcaire bitumineux d'Orbagnoux (Ain). Bulletin de la Société d'Histoire Naturelle d' Autun 6:1-17.

Savornin MJ. 1915. Les pycnodontes eocenes de i'Algerie. Comptes Rendus, Association Francaise pour I'Avancement de Science 43:368-377.

Sferco E, López-Arbarello A, Báez AM. 2015. Anatomical description and taxonomy of $\nmid$ Luisiella feruglioi (Bordas), new combination, a freshwater teleost (Actinopterygii, Teleostei) from the 
Upper Jurassic of Patagonia. Journal of Vertebrate Paleontology 35(3):e924958

DOI 10.1080/02724634.2014.924958.

Shibuno T, Nakamura Y, Horinouchi M, Sano M. 2008. Habitat use patterns of fishes across the mangrove-seagrass-coral reef seascape at Ishigaki Island, southern Japan. Ichthyological Research 55(3):218-237 DOI 10.1007/s10228-007-0022-1.

Simon KD, Bakar Y, Temple SE, Mazlan AG. 2010. Morphometric and meristic variation in two congeneric archer fishes Toxotes chatareus (Hamilton 1822) and Toxotes jaculatrix (Pallas 1767) inhabiting Malaysian coastal waters. Journal of Zhejiang University Science B 11(11):871-879 DOI 10.1631/jzus.b1000054.

Stensiö E. 1935. Sinamia zdanskyi, a new amiid from the Lower Cretaceous of Shantung, China. Paleontologia Sinica, Series C 3:1-148.

Su DT. 1973. A new Sinamia (S. huananensis, sp. nov.) from the Upper Jurassic of Southern Anhui. Vertebrata PalAsiatica 11:149-153.

Taverne L. 1997. Les poissons crétacés de Nardo $5^{\circ}$ Pycnodus nardoensis sp. nov. et considérations sur l'ostéologie du genre Pycnodus (Actinopterygii, Halecostomi, Pycnodontiformes). Bolletino del Museo civico di Storia naturale di Verona 21:437-454.

Taverne L. 2003. Les poissons crétacés de Nardò. 15. Etude complémentaire de Pseudopycnodus nardoensis (Taverne, 1997) nov. gen.(Actinopterygii, Halecostomi, Pycnodontiformes). Bollettino del Museo Civico di Storia Naturale di Verona, Geologia Paleontologia Preistoria 27:15-28.

Taverne L, Nolf D. 1978. Troisième note sur les poissons des Sables de Lede (Eocène belge): les fossiles autres que les otolithes. Bulletin de la Société Belge de Géologie 87:125-152.

Thies D, Hauff RB. 2011. A new species of Dapedium Leach, 1822 (Actinopterygii, Neopterygii, Semionotiformes) from the Early Jurassic of South Germany. Palaeodiversity 4:185-221.

Tintori A. 1981. Two new pycnodonts (Pisces, Actinopterygii) from the Upper Triassic of Lombardy (N. Italy). Rivista Italiana di Palaeontologia e Stratigrafia 86:795-824.

Tintori A. 1990. The actinopterygian fish Prohalecites from the Triassic of Northern Italy. Palaeontology 33:155-174.

Tintori A, Zuoyu S, Peigang N, Lombardo C, Dayong J, Motani R. 2015. Oldest stem Teleostei from the Late Ladinian (Middle Triassic) of Southern China. Rivista Italiana di Paleontologia e Stratigrafia 121:285-296 DOI 10.13130/2039-4942/6519.

Tuset VM, Farré M, Lombarte A, Bordes F, Wienerroither R, Olivar P. 2014. A comparative study of morphospace occupation of mesopelagic fish assemblages from the Canary Islands (Northeastern Atlantic). Ichthyological Research 61(2):152-158 DOI 10.1007/s10228-014-0390-2.

Veiga Ferreira O. 1961. Fauna ictyologica do Cretacico de Portugal. Communicaçoes dos Serviços Geológicos de Portugal 45:249-278.

Vescogni A, Bosellini FR, Papazzoni CA, Giusberti L, Roghi G, Fornaciari E, Dominici S, Zorzin R. 2016. Coralgal buildups associated with the Bolca Fossil-Lagerstätten: new evidence from the Ypresian of Monte Postale (NE Italy). Facies 62(3):1-20 DOI 10.1007/s10347-016-0472-x.

Volta GS. 1796. Ittiolitologia Veronese del Museo Bozziano ora Annesso a Quello del Conte Giovambattista Gazola e di altri Gabinetti di Fossili Veronesi con la Versione Latina. Verona: Stamperia Giuliari.

Webb PW. 1982. Locomotor patterns in the evolution of actinopterygian fishes. American Zoologist 22(2):329-342 DOI 10.1093/icb/22.2.329.

Weitschat W. 2008. Intraspecific variation of Svalbardiceras spitzbergensis (Frebold) from the Early Triassic (Spathian) of Spitsbergen. Polar Research 27(3):292-297

DOI 10.1111/j.1751-8369.2008.00041.x. 
Wetherbee BM, Holland KN, Meyer CG, Lowe CG. 2004. Use of a marine reserve in Kaneohe Bay, Hawaii by the giant trevally, Caranx ignobilis. Fisheries Research 67(3):253-263

DOI 10.1016/j.fishres.2003.11.004.

White EI. 1934. Fossil fishes from Sokoto province. Bulletin of the Geological Survey of Nigeria 14:1-78.

Wilson GG. 1998. A description of the early juvenile colour patterns of eleven Lethrinus species (Pisces: Lethrinidae) from the Great Barrier Reef, Australia. Records of the Australian Museum 50(1):55-83 DOI 10.3853/j.0067-1975.50.1998.1274.

Woodward AS. 1908. On some fish-remains from the Lameta beds at Dangargaon, Central Provinces. Palaeontologia Indica 3:1-6.

Woodward AS. 1918. The fossil fishes of the English Wealden and Purbeck Formations. Part 2. Monographs of the Palaeontographical Society 70:49-104.

Wretman L, Blom H, Kear BP. 2016. Resolution of the Early Jurassic actinopterygian fish Pachycormus and a dispersal hypothesis for Pachycormiformes. Journal of Vertebrate Paleontology 36(5):e1206022 DOI 10.1080/02724634.2016.1206022.

Xu GH, Shen CC, Zhao LJ. 2014. Pteronisculus nielseni sp. nov., a new stem-actinopteran fish from the Middle Triassic of Luoping, Yunnan Province, China. Vertebrata PalAsiatica 52:364-380.

Zelditch M, Swiderski D, Sheets DH, Fink W. 2004. Geometric Morphometrics for Biologists: A Primer. Waltham: Elsevier Acade, MIC Press.

Zhang MM, Zhang H. 1980. Discovery of Ikechaoamia from South China. Vertebrata PalAsiatica 18:89-93. 